\title{
Henry Felix Woods and the Black Sea/Bosphorus Entrance Maritime Safety System, Then and Now
}

\section{Caroline Finkel}

Les risques associés à la navigation dans la mer Noire étaient bien connus, particulièrement au confluent de la mer et du Bosphore. Des navires qui transportaient les précieux produits du bassin de la mer Noire à leur mise en marché ont sombré dans cette région. Dans les années 1860, une commission a été mise sur pied pour examiner des façons de réduire ces pertes. Le présent article revient sur ses délibérations et sur le rôle de premier plan joué dans l'établissement d'un système de sécurité maritime par le lieutenant de navigation Henry Felix Woods, spécialiste de la navigation de la Marine royale. Bon nombre des structures du système qui subsistent encore aujourd'hui ont été trouvées et photographiées par des membres du groupe de randonnée HikingIstanbul.

Several years ago, when exploring the Black Sea coast east of the Bosphorus, ${ }^{1}$ the handful of hikers who then constituted the now numerous HikingIstanbul hiking group $^{2}$ came upon a cluster of distinctive, low buildings atop a cliff. Below, on a

\footnotetext{
1 This spelling of the Bosporus may seem unfamiliar to English language readers. The Times Atlas uses "Bosporus," and has at least since 1898. However, as Woods in his memoir spelled it "Bosphorus" that is what is being used here. (Editor)

2 HikingIstanbul has been exploring Istanbul's hinterland since winter 2013-14: https://www. facebook.com/hikingistanbul. A guide to our hikes is in progress, which also contains essays on many aspects of Istanbul's hinterland that is being lost to rampant construction. Photographs are
}

The Northern Mariner / Le marin du nord, XXX, No. 4 (Winter 2020), 379-418 


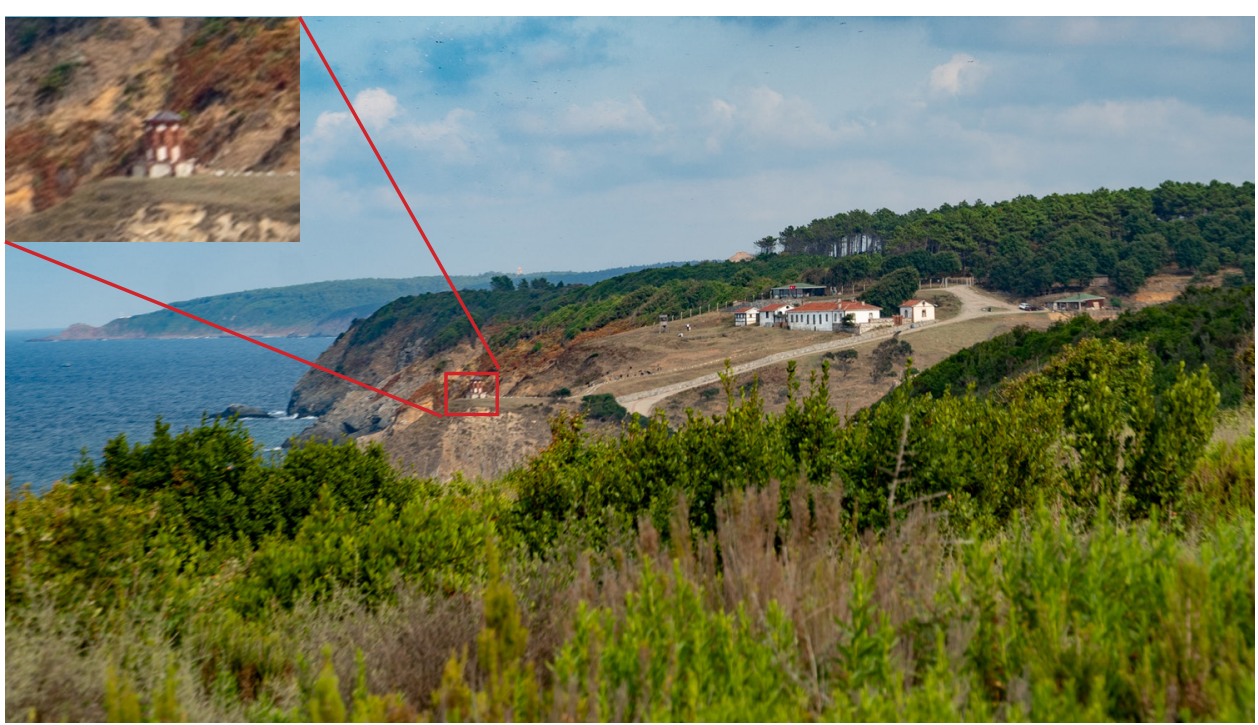

İngiliz evleri, looking east to Karaburun headland

knoll, stood a ruined brick tower (indicated by the arrow in the photograph). ${ }^{3} \mathrm{We}$ had no idea what these structures were, but learnt from local people that the place is today called "Ingiliz evleri," or "English houses." Back home, we discovered from a Turkish blog that they were part of the network of structures of the Black $\mathrm{Sea} /$ Bosphorus entrance maritime safety system established in the late 1860 s with the close involvement of the British, and most notably of Navigating Lieutenant Henry Felix Woods, later Admiral Sir Henry Felix Woods Paşa of the Sultan's navy. ${ }^{4}$ As we continued to hike the coasts on both sides of the Bosphorus, we found other buildings and towers of similar appearance and resolved to investigate their history.

Writing in a time of lockdown, when libraries and archives are difficult of access, we have decided nevertheless to bring together the written sources and photographs already in our possession. This article does not, therefore, claim to reveal every twist and turn of the process of reducing the loss of men and cargo by shipwreck in the waters of the Black Sea/Bosphorus entrance in the mid nineteenth century. Rather, it focuses on the action taken by Woods and his associates to

by Nick Hobbs unless otherwise indicated; additional photo credits are: OG Oytun Güventürk; CF Caroline Finkel.

3 I am grateful for various sorts of support and inspiration to İdris Bostan, Alaaddin Tok, Gülsün Tanyeli, Suha Ülgen, Colin Heywood, Evan Moody, Sheree Barka and Fiona Slay, as well as to the hikers of HikingIstanbul. I also thank staff at the UK Hydrographic Office and The National Archives, while the reviewers whom Northern Mariner assigned to the task made very helpful suggestions. Remaining errors are my own.

4 I am no longer able to trace this blog, but among the many more recent social media postings of its author, Mehmet Akif Delipoyraz, historian of the Riva district (a strategic location just outside the Bosphorus entrance discussed below), is an entry that gives brief information about the subject matter of this article: https://m.facebook.com/RivaTemsilcisi/photos/ a.10153709557138725/ $10154053043948725 /$ ?type $=3$. 


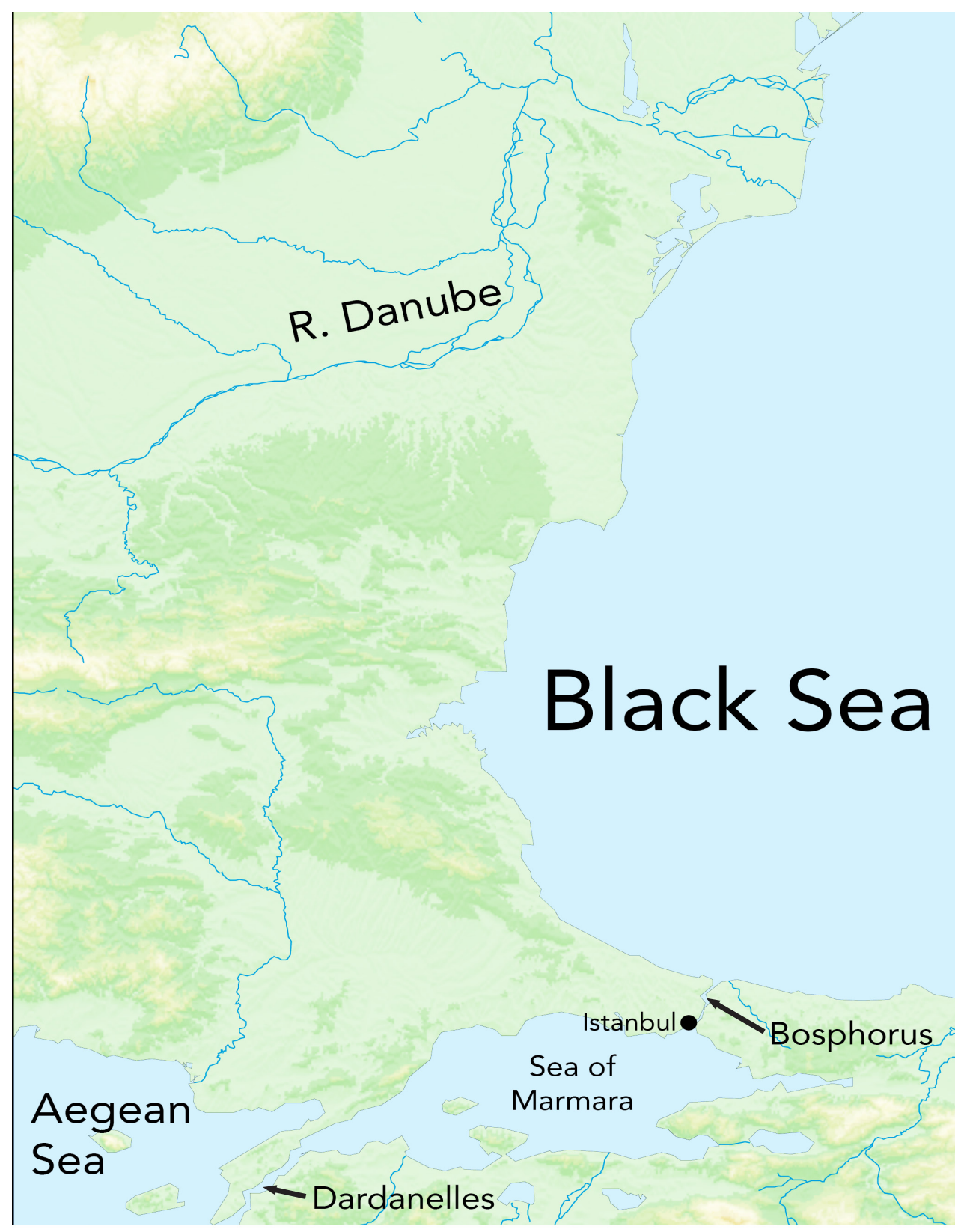

The Aegean Sea is the body of water north of Crete, east and south of Greece and west of Turkey. The Dardanelles are the strait flowing roughly NE/SW that connect it to the Sea of Marmara. The Bosphorus, flowing generally north/south, connects the Sea of Marmara with the Black Sea. This strait also serves as the boundary between Europe, on the west coast, and Asia on the east side. The comparatively featureless south shore of the Black Sea either side of the entrance to the Bosphorus, on an east/west axis, can make a safe entrance for a ship into the Bosphorus navigationally difficult if not dangerous. Hence the need for the Black Sea/Bosphorus entrance maritime safety system discussed here. 


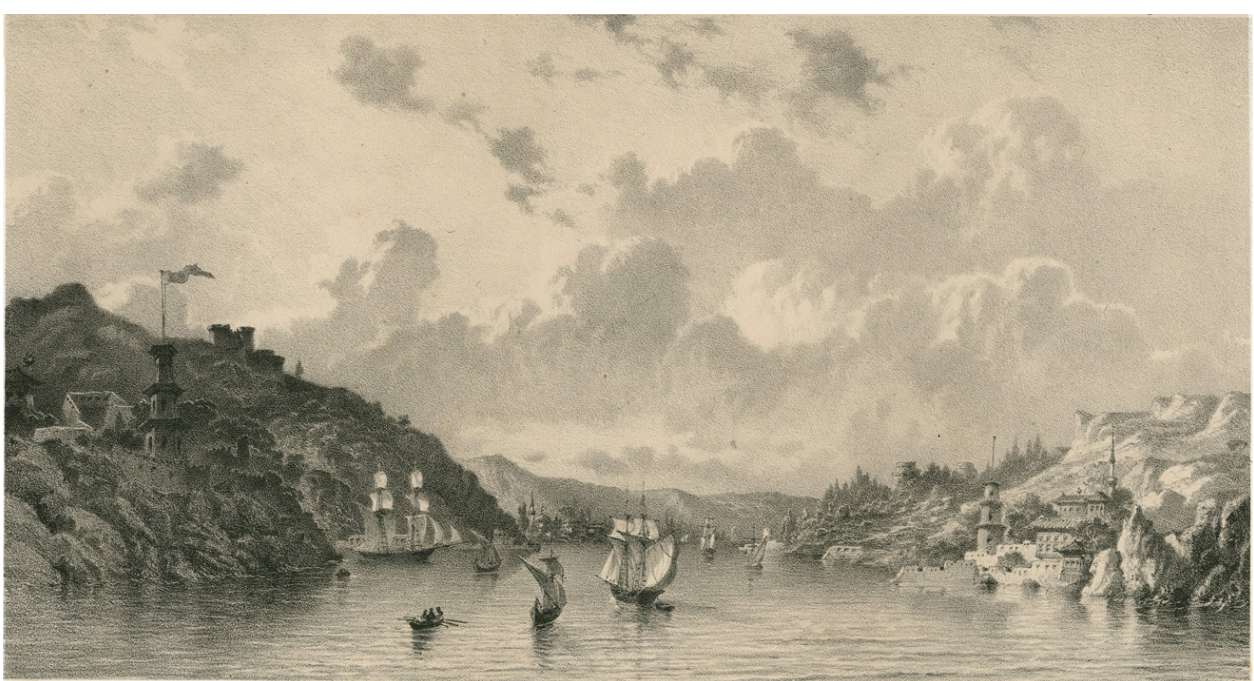

View of the rugged entrance to the Bosphorus from the Black Sea, with the lighthouse at Rumeli Feneri and the supposed Clashing Rocks on the European coast, and the lighthouse at Anadolu Feneri on the Asian coast. (Eugène Flandin, "Entrée du Bosphore," Wikimedia Commons)

mitigate the risks of sailing here. It combines a narrative of his involvement in this endeavour with, in the inventory, images of the extant structures of the maritime safety system that we have seen on our hikes.

Constantinople, formally renamed Istanbul in 1930, has been a fabled city throughout history. ${ }^{5}$ Beyond it lay the "hostile sea" of antiquity, whose horror and mystery is echoed in its later name of "Black." The Argonauts' passage through these waters in their quest for the Golden Fleece was once familiar to every child read the Greek myths at bedtime, but few of us knew the location of the Clashing Rocks these adventurers had to negotiate on their voyage to Colchis at the eastern end of the Black Sea.

Nor did we realise that the Clashing Rocks were only the most celebrated of the perils awaiting mariners venturing to and from the Black Sea. The sea itself was feared for its storms and currents: the difficulties of finding the Bosphorus entrance caused particular anxiety for vessels sailing south, and shipwreck for the unlucky. Ancient authors write of temples on the cliffs above the mouth of the strait, where mariners prayed for a calm voyage before setting out, and once safely returned, visited to thank the Gods. Visitors to the village of Rumeli Feneri can still see atop one of the supposed Clashing Rocks a column base that is thought to be the remains of a temple to Apollo. ${ }^{6}$ With the Greek colonies around its coasts long gone, and the medieval Venetian and Genoese colonies no more, the sea became

\footnotetext{
5 Woods and other contemporary sources consulted here refer to the city as Constantinople; we have followed their usage.

6 Gizem Dörter, "A Future for the Upper Bosphorus: A Historical Survey for the Upper Bosphorus, and a Proposal for a Sustainable Heritage Management Plan" (MA thesis, Koç University, Istanbul, 2010), 34-35.
} 


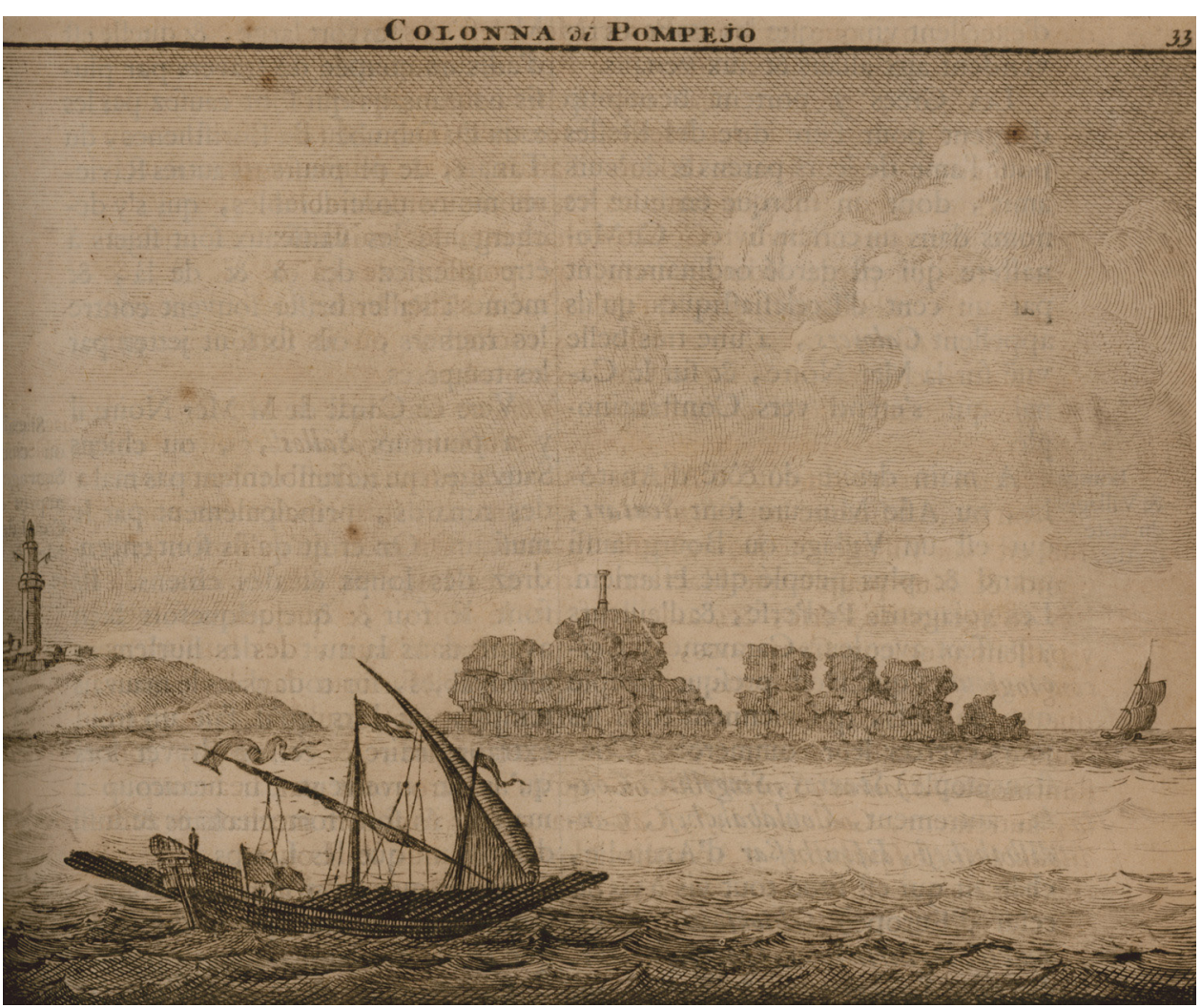

The supposed Clashing Rocks, with the so-called "Column of Pompejo" atop, and Rumeli Feneri lighthouse on the adjacent headland where the Bosphorus and Black Sea meet. (Cornelis deBruyn. Voyage au Levant, c'est-à-dire, dans les principaux endroits de l'Asie Mineure, dans les isles de

Chio, Rhodes, et Chypre etc. (Paris, 1714))

an "Ottoman lake," and the lands bordering it provided resources essential to life in the imperial capital.

Given the Black Sea basin's centrality to Ottoman wellbeing, and the constant back and forth of commercial and other vessels, the risks of sailing its waters loomed large in the contemporary imagination. The seventeenth century traveller and polymath Evliya Çelebi, widely considered the greatest of Ottoman literary figures, reminded his readers of the sea's power by including in his magnum opus a long and vivid account of his experience of shipwreck off Balaklava on the Crimean peninsula in $1641 .^{7}$ Evliya's modern detractors delight in accusing him of invention and exaggeration in what they erroneously read as a straightforward, documentary recounting of his journeys. However, even if events might not entirely have befallen as he describes, the fact that he includes such an episode shows that he knew it would strike a chord with his readers. The perils to be faced were human

7 Robert Dankoff and Sooyong Kim (translation and commentary), An Ottoman Traveller. Selections from the Book of Travels of Evliya Çelebi (London: Eland Books, 2010), 47-54. 
made as well as natural: no one could still the storms, but the Ottoman authorities took steps to minimise hazards where they might, for example by taking punitive action against any who burned flares on either side of the Bosphorus mouth to mislead the shipping whose wrecks they then looted. ${ }^{8}$

As a result of the commercial agreement of 1838 known as the Treaty of Baltaliman1, Ottoman monopolies were abolished and foreigners gained advantage in the terms of trade. The Ottoman territories on the Danube were the particular focus of British interests because with the introduction of steamship navigation on that river in 1830, the abundant grain harvests of the region could be more profitably extracted: immediately before the Crimean War of 1853-56, some 40 percent of the ships leaving the Danube carried grain to British ports. Years of wrangling between the riverine states and other interested parties over the status of the river and access to its waters followed, but as agreement was reached, trade burgeoned. ${ }^{9}$ The onward road to market lay via the Bosphorus. Frequent loss of vessels attempting this passage was a significant financial consideration, and finding a way to ensure the safety of shipping was urgent.

There had been lights at the Bosphorus mouth for centuries, possibly ever since antiquity. ${ }^{10}$ Immediately after the Crimean War, French specialists were charged by the Porte with improving the Ottoman lighthouse network, first of all the some twenty lights in the Dardanelles, the Marmara, the Bosphorus and the Black Sea. The modernised lighthouses came into service early in the $1860 \mathrm{~s}$, but objections by the British in particular - under Ambassador Sir Henry Bulwerdelayed the formal conclusion of arrangements for their functioning. Arguments revolving around their financing and administration were exacerbated by a dose of Anglo-French rivalry. ${ }^{11}$

The problem of increasing the safety of shipping entering the Bosphorus from the north had long exercised an Austrian engineer from Venice named Schultze, who in early 1863 proposed that a line of buoys be set up on either side of its entrance. At the same time, a maritime expert called Hopper published his own plan, which was to build beacons along the coasts on either side of the strait, establish rocket batteries and lifeboat stations and, at some distance out to sea, anchor buoys with bells attached in line with its mouth. Hopper's plan prompted the setting up of a commission to study the issue, but it never met. In September

\footnotetext{
8 e.g. 6 Numaralı Mühimme Defteri,(Ankara: T.C. Başbakanlık Devlet Arşivleri Genel Müdürlüğü, Osmanlı Arşivi Daire Başkanlığı, 1995), 1: 110 (order dated 1564CE); 12 Numaralı Mühimme Defteri, (Ankara: T.C. Başbakanlık Devlet Arşivleri Genel Müdürlüğü, Osmanlı Arşivi Daire Başkanlığı, 1996), 1: 411 (order dated 1571 CE); Murat Torun, "III Numaralı (H.983-984/M.1575-1576) Tarihli Mühimme Zeyli Defterinin Transkripsiyon ve Değerlendirilmesi (S.1-175)" (MA thesis, Marmara University, Istanbul, 2014), 220-21, 229 (orders dated 1576 CE).

9 Constantin Ardeleanu, The European Commission of the Danube, 1856-1948: An Experiment in International Administration (Leiden: Brill, 2020), 34-36, 50ff, $285 \mathrm{ff}$.

10 Dörter, 27-29.

11 Jacques Thobie, L'Administration générale des phares de l'Empire ottoman et la Société Collas et Michel (1860-1960) (Paris: L'Harmattan, 2004), 9-30.
} 


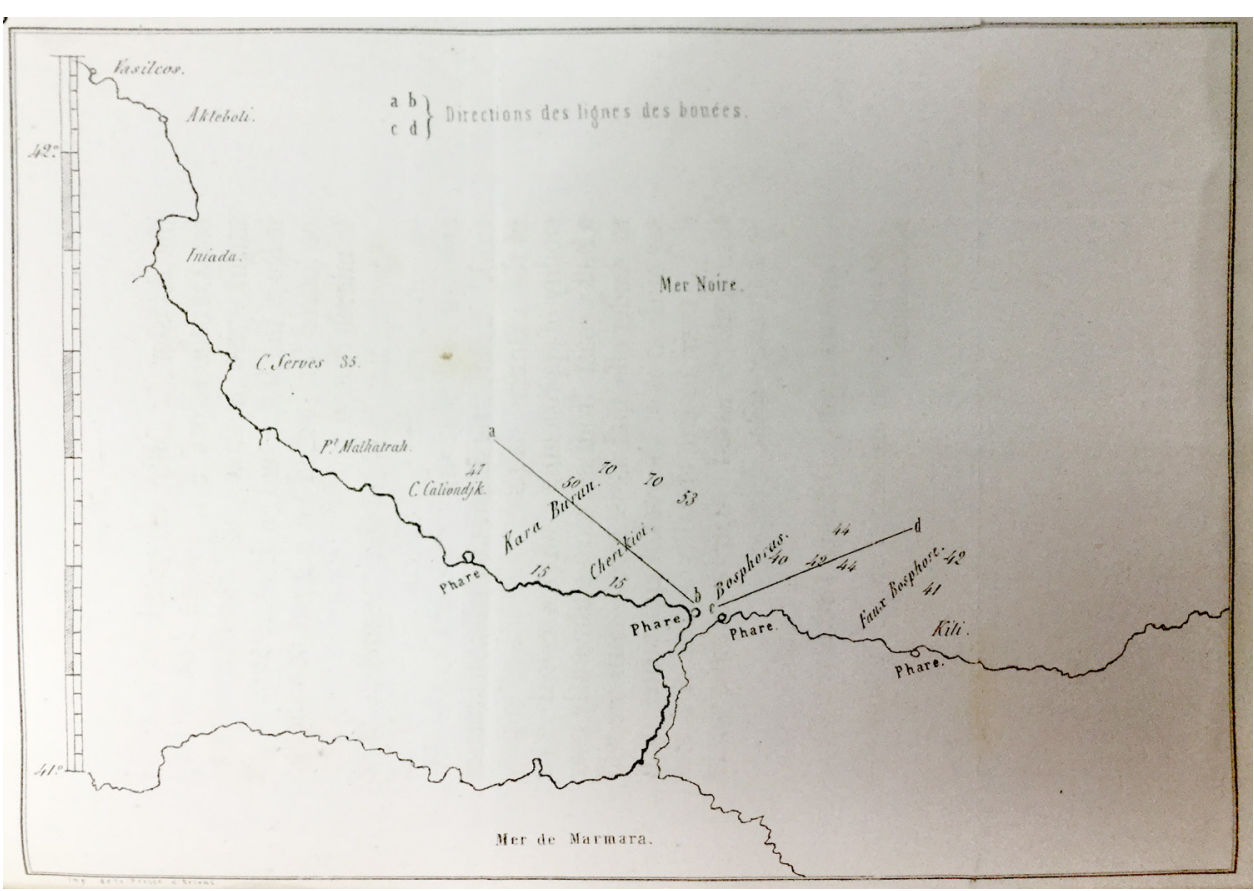

Map of the Black Sea coasts showing proposed lines of buoys to funnel ships safely into the Bosphorus, as sketched by Bödtker. (TNA, F0195/847, 535)

of the same year, after consulation with mariners who knew the Black Sea well, the consul general of Sweden-Norway, Anker Bödtker, produced a third report combining those of Schultze and Hopper. ${ }^{12}$

Bödtker stated that the majority of shipwrecks at the Bosphorus entrance took place between Karaburun on the European side and Şile (called Kilia, in his report ${ }^{13}$ ) on the Asian side - we will continue to use the terms "European" and "Asian" that appear in our documents - these two headlands being the range within which vessels made the approach to the strait. He wrote that the topography was so disorienting that mariners were unable to calculate their position: the few available landmarks could only be seen in clear weather, and there were shifting currents; the heights were wreathed in fog except in summer, and nautical observation was rendered impossible and the coastal lighthouses were invisible. ${ }^{14}$

Bödtker noted that lines of buoys had been used to good effect elsewhere, even where the current was stronger than in this case. He proposed revising the angles of the two lines of buoys extending from the Bosphorus mouth that Schultze had suggested, and recommended that there be seventy-five buoys on the European side, at three per "English mile," running to a point twelve miles off Karaburun, and sixty on the Asian side, running to a point eleven miles off Kilia/Şile. Each line

12 Project de mesures pour faciliter aux navigateurs l'entrée de Bosphore par Anker Bödtker, September 1863, The National Archives, Kew, London (TNA), FO195/847, 520-21.

13 Ibid., 535.

14 Ibid., 521. 


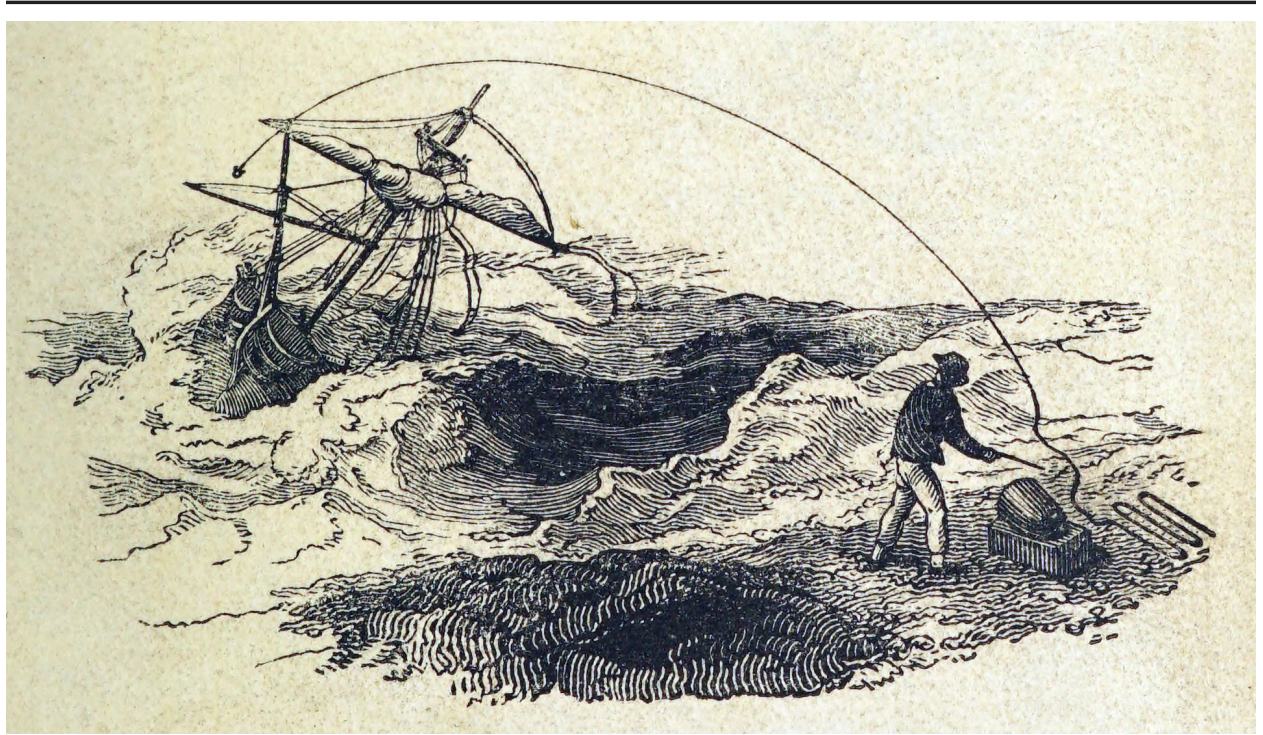

A rocket being fired to a stricken vessel. (G. W. Manby, An Essay on the preservation of shipwrecked persons, Internet Archive)

of buoys would be distinctive in colour and their bells would have different tones. A lightship supplied with bells and cannons would be anchored at the end of each line of buoys, to guide vessels at night and in fog. Bödtker added that lightships had also already been successfully deployed in difficult seas elsewhere. ${ }^{15}$

Schultze had not seen the utility of coastal beacons, but Bödtker insisted on their value to alert vessels to take immediate action if they found themselves on the wrong, shore-, side of the lines of buoys. Even in periods of fog, he wrote, there were times when it lifted and beacons could be seen. Beacons were easily constructed and, as Hopper had advised, should be built between Karaburun and Kilia/Şile, close to the shore but at sufficient height to be visible from far out to sea. Bödtker proposed that one of the beacons be built near the "false Bosphorus," a second east of Kilia/Şile, and a third west of Karaburun. ${ }^{16}$

Appended to Bödtker's report is a sketchmap that marks "False Bosphorus" on the Asian side, to the west of Şile (here shown as Kili). ${ }^{17}$ In a sailing companion of 1847, the "False Bosphorus" is described as being fifteen miles east of the actual entrance to the strait, and as being "very deceptive." "It may be known from the true one by observing that the land to the westward of it is high, rugged and irregular: whereas land similar to that is to the eastward of the true entrance; the land to the westward of which is not so high, and is more uniform, diminishing gradually to what appears a cape, which is probably Karabournou." 18

15 Ibid., 522-23.

16 Ibid., 523-24.

17 Ibid., 535.

18 J. S. Hobbs, New Sailing Directions for the Dardanelles, Sea of Marmara, Bosphorus, Black Sea and the Sea of Azov (London: Charles Wilson, 1847), 15. 
Confusingly, there is a cape called Karabournou (Karaburun) on the coast on both sides of the Bosphorus: the description above locates "False Bosphorus" to the west of the Karaburun headland on the Asian side. Some English-language sources of the 1860s give the Turkish name-Yalan Boğaz —of which "False Bosphorus" is a literal translation.

At the time, there were four lighthouses on the stretch of coast in question: one on each side of the Bosphorus mouth - in the villages today called Rumeli Feneri and Anadolu Feneri - one at Karaburun and another at Şile. Bödtker recommended that the latter pair be painted a different colour from the former. ${ }^{19}$

Preventing shipwrecks was one thing; assisting the shipwrecked and salvaging cargo was equally vital. Hopper's plan had called for lifeboats as a key feature of the maritime safety system, but Bödtker thought that few would be needed if his proposed plan worked well. This, he noted, would be an advantage on a difficult and sparsely-settled coast whose people were inexperienced in sea rescue. ${ }^{20}$

Bödtker hoped that the Porte could be prevailed upon to meet the costs of the new safety system from the levies paid by vessels. He suggested that one way to limit expenses would be for the garrisons of the forts along the coast to man the lifeboats. Better still, this work could be performed by men from the imperial fleet stationed in these forts. Hopper had also proposed the use of rocket batteriesdevices that shoot a line offshore to the foundering ship to assist transferring the crew to safety. ${ }^{21}$ Bödtker suggested that money could also be saved if these too were operated by the coastal garrisons. ${ }^{22}$

Bodtker had no expectations that the costs of the maritime safety system could be met by voluntary contributions from private individuals, the insurance companies or the foreign governments involved. He laid out the significant costs already borne by these parties, making the case that the new proposals were a national rather than an international project, and insisting that the Porte should pay. He emphasised the advantages that greater maritime safety would bring to the empire's commerce, and argued eloquently that Ottoman shipping had more to gain from the improvements than did foreign vessels. ${ }^{23}$

Being among the parties most concerned with the question of safety, the agents of the marine insurance companies based in Constantinople expressed wholehearted approval of Bödtker's recommendations, and hoped the Porte would move forward with this "national" undertaking. ${ }^{24}$ In a response signed by "forty masters of ships of different nationalities," the agent of the Norwegian insurance company, Schött, suggested improvements. Ships often found themselves close to the coast too late

19 Project de mesures, September 1863, TNA, FO195/847, 524.

20 Ibid.

21 https://en.wikipedia.org/wiki/Henry_Trengrouse;https://www.coastguardsofyesteryear.org/ photogallery.php?photo_id=174

22 Project de mesures, September 1863, TNA, FO195/847, 523, 525.

23 Ibid., 526-28.

24 Ibid., 529-31. 
to take evasive action, he wrote, and while he endorsed the utility of beacons when the coast was clear of fog, he asserted that numbered bell-buoys were the most essential equipment of all, and would allow captains who reached the lines of buoys to set a safe course to the Bosphorus mouth. He observed that this was a tool that worked well in similar conditions elsewhere. ${ }^{25}$

The experience and voices of Schött's informants shine through his proposals. While he acknowledged that rockets would have to be moved along the poor coastal roads to where a ship was wrecked, he approved of their inclusion in the safety system on the grounds that they might save lives, and argued that the fact that rescue might be imminent would console the stricken. So too, although he echoed Bödtker in questioning the utility of lifeboats, adding that it would be impossible for

\section{SPUNYARN}

From the Strands of a Sailor's Life

Afloat and Ashore

FORTY-SEVEN YEARS UNDER

THE ENSIGNS OF GREAT BRITAIN AND TURKEY

By Sir HENRY F. WOODS, K.C.V.O.,

Late Admiral and Pasha in the Imperial Ottoman Naval Service. Grand Cordon of the Medijeh and Osmanieh. K.C. of the Saxe-Coburg Order.

Aide-de-Camp for some years to the late Sultan Abdul Hamid.

VOL. I.

With Frontispiece and Ig otber Illustrations.

LONDON: HUTCHINSON \& CO. PATERNOSTER ROW I024. them to approach a foundering ship on this rocky coast, he concluded that they should be an element in the system, even if they contributed to saving few lives. ${ }^{26}$

A Foreign Office memorandum dating from 1881 summarises progress on the maritime safety project and indicates that the agents of the marine insurance companies in Constantinople had approached Ambassador Bulwer in April 1864, "with the view to the adoption of measures for preventing the dangers to which ships were exposed when making the Bosphorus at the Black Sea entrance." It was two more years before the matter again appeared on the agenda, when the Board of Trade proposed that the ambassador, now Lord Lyons, might ally with his fellow ambassadors to urge the Porte to act. ${ }^{27}$

On 14 September 1866, Lord Lyons wrote on behalf of his fellow ambassadors to the Ottoman foreign minister, Ali Paşa, about measures that might be taken to improve the safety of shipping; an earlier approach had gone unanswered. Lyons' first concern was for the victims, and he listed the measures considered most urgent. These were the construction of shelters for the protection of the shipwrecked, the

\footnotetext{
25 Ibid., 532-35.

26 Ibid.

27 Memorandum respecting the Light-ship and Life-boat Service in the Black Sea and Bosphorus, 11 May 1881, TNA, FO881/4428, 1-2.
} 
establishment of rocket batteries, and surveillance of the coasts in order to know that a ship had been wrecked and there were victims to be rescued, as well as to prevent wrecked ships being looted. He appealed to the Ottoman government's humanity and, emphasising also the commercial losses, wrote that the time had come for firm action. He observed that the season was advancing, and if nothing practical was done now, conditions would soon make it impossible to take the necessary steps this year. Lyons requested that a Mixed Commission be established, at the very least. He thought it possible that shipping using this route would agree to contribute to the costs of improving safety. ${ }^{28}$

Winter came without any visible action on the part of the Porte. Early in 1867, "a number of British captains of vessels trading to the Black Sea" leaned on Lyons to press more energetically for a response, and later that year the Porte acceded to appointing a commission to draw up a scheme for "preventing shipwrecks." ${ }^{29}$ The British delegate initially appointed to the commission was the commanding officer of Caradoc, the dispatch vessel attached to the British embassy. He soon resigned in favour of his recently appointed second in command, Second Master Henry Felix Woods, whom he thought was better suited for the work. ${ }^{30}$

Woods was born on 18 July 1843 and at the age of 10 had been nominated to attend the Upper School at the Greenwich Hospital (now the Royal Hospital School). The school had a connection from its beginning with the naval and merchant services, and "in the course of its existence ... it supplied the Navy with its most skilful navigators and hydrographers. ${ }^{31}$ In 1858 Woods left the school to join the Royal Navy as a master's assistant. This rank was equivalent to midshipmen but the rank title then used by navigation specialist branch which was distinct from executive branch, or seamen officers. Woods spent six years on foreign service as a navigation specialist, and shortly before he returned to England for necessary exams, his commanding officer "told [Woods] of his intention to recommend me as strongly as he could for an appointment in the Surveying Service, for which he considered me eminently suited, and that he would push the matter when he went to the Admiralty." ${ }^{\prime 32}$ Woods wrote his exams in March 1867 and at the end of the month was appointed as a second master to Caradoc. Having passed his exams near the top of the class, in November he was promoted to navigating lieutenant." ${ }^{33}$

Woods presents himself as the sole active member of the commission, more properly called the International Commission for the Improvement of the

28 Lord Lyons to Aali Pacha, 14 September 1866, TNA, FO195/847, 556-57.

29 Dundee Courier \& Argus, 11 January 1867.

30 Sir Henry F. Woods, KCVO, Spunyarn. From the Strands of a Sailor's Life Afloat and Ashore (London: Hutchinson \& Co, 1924), 1: 268

31 Ibid., 1: 12.

32 Ibid., 1: 148.

33 Ibid., 1: 268; cf. Yusuf Osman, "British Employees of the Ottoman Government: the Paşas Hobart and Woods" (PhD thesis, University of London, 2019), 60. 
Navigation of the Black Sea Entrance to the Bosphorus etc. ${ }^{34}$ Most members, he writes, gave little energy to the maritime safety project and left the work to a sub-committee of which he became chair; his fellow members were the Ottoman delegate and an engineer from Austrian Lloyd Mail Services. The former "would accept no responsibility" and the latter was too busy. Woods writes that it became "a one man's job." 35

By October 1867, the commission had requested reports on the erection of beacons, the establishment of rocket batteries and lightships, electrification of the existing lighthouses, and fog signals. ${ }^{36}$ Woods tells us that he rode along the Black Sea beaches in order to assess the situation at first hand. Here he saw evidence of shipwrecks, and observed that because settlement lay well back from the shore, these would go unnoticed except when they occured near the coastal villages of Riva and Şile (here, Shillee). Moreover, he noted, any survivors who did make it to shore risked dying of exposure. As well as beacons, rocket batteries and a lightship, he recommended refuge houses provided with blankets and warm clothing, and two lifeboats on each coast. Woods also uses the term "false Bosphorus," but he reckoned there were two: one at Terkos, west of the Bosphorus where the lagoon of the same name links to the sea (see Terkoz on the Rescue Stations map, at the extreme west side on p. 394), and the other, as earlier noted, at Şile (see Rescue Stations map, p. 395).

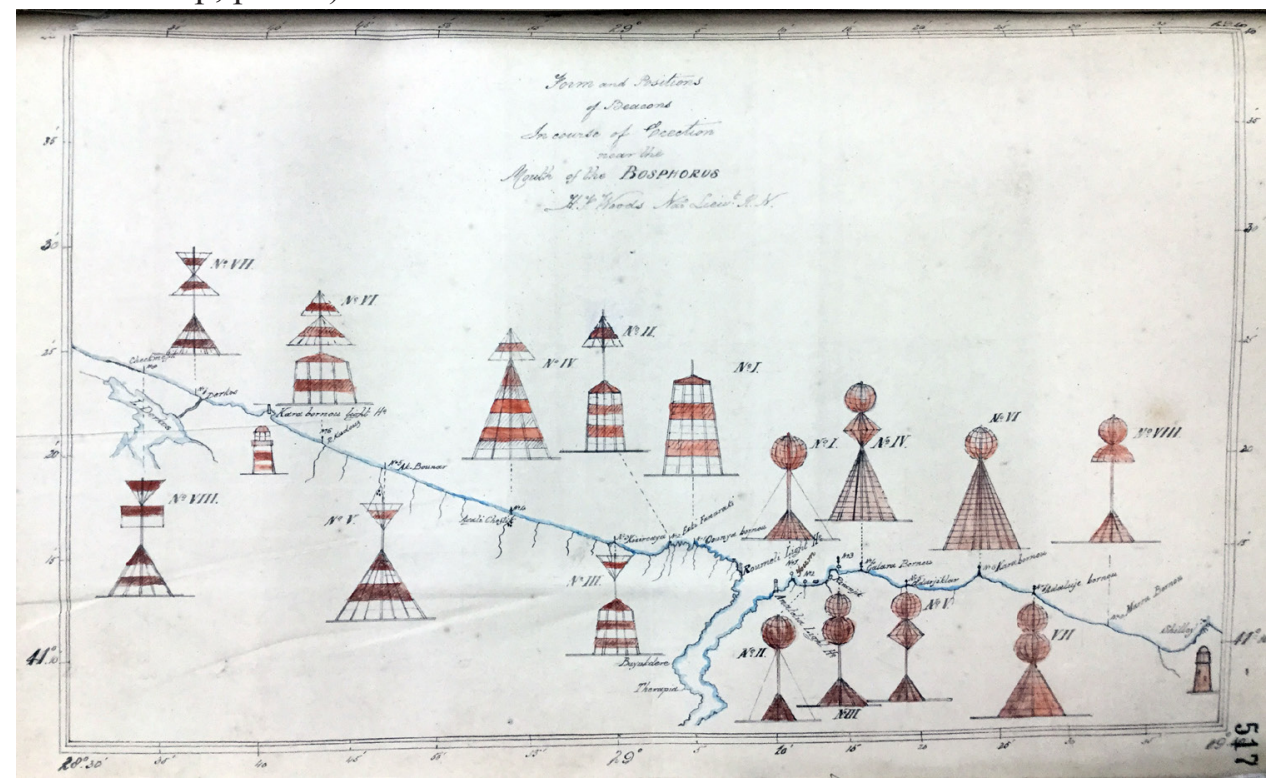

Woods' plan for the "Form and Positions" of the coastal beacons (TNA, F0195/847, 517)

\footnotetext{
34 Henry F. Woods to Ambassador Henry Elliot, 29 April 1869, TNA, FO195/847, 543.

35 Woods, Spunyarn, 1: 270.

36 Memorandum, 11 May 1881, TNA, FO881/4428, 2-3.
} 
Woods was accompanied in his work by Ahmed Bey. Although Woods described him as assistant, in reality he was a colleague of equal standing. His father had commanded the Ottoman fleet at the Battle of Sinop, a casus belli for the Crimean War. Ahmed was the Ottoman delegate to the commission, the man earlier described by Woods as refusing to take responsibility having presumably stepped down. Ahmed had gained the rank of lieutenant colonel by 1869. The two men were clearly good friends, and Woods recounts sharing dinners at the end of the day. ${ }^{37}$

Woods claims credit for the scheme to anchor a lightship at the Bosphorus entrance. Fellow commission members had apparently declared this an act of madness, but alongside the vice consuls on the commission who were, he opines, "men of no experience whatever," were others who were sailors like himself. Having sailed the Atlantic and the Cape of Good Hope, Woods thought his proposal perfectly feasible. He lost his temper, he says, but once his colleagues had signed the protocol, he ordered plans for a lightship with all necessary equipment from Trinity House, the maritime authority in London responsible for lighthouses and other aids to navigation. He offered to take the ship to its location himself, and to spend the first winter month aboard..$^{38}$

Woods', and perhaps the commission's, momentum was almost lost when he was promoted to navigating lieutenant in November $1867^{39}$ and ordered home. Bödtker was also a commission member and, a strong ally of Woods, "harangued" its other members. They agreed to petition the ambassador, who was by then Henry Elliot. He forwarded a letter to London with the result that Woods was able to remain in Constantinople and continue his work..$^{40}$ Elliot later confirmed that the lion's share of the commission's work had indeed "devolved upon Mr Woods."

Woods" plan for the coastal beacons has survived. It is entitled "Form and Positions of Beacons In course of Erection near the Mouth of the BOSPHORUS. H.F. Woods Nav Lieut R.N.," and marks where each should be situated-eight on the European coast and eight on the Asian. The plan is coloured and the form of each individual beacon is shown, as well as the existing lighthouses on each side of the Bosphorus mouth and at Karaburun and Şile. ${ }^{42}$ The accompanying "Notice to Mariners" adds detail: the beacons on the European coast would be surmounted by a cone and painted in red and white horizontal bands and the Karaburun lighthouse would be similarly painted; the beacons on the Asian coast would be surmounted by a globe and painted light red, like the Şile lighthouse. The globes and cones were being made of "light iron frame-work covered with basket work" and the lower part of the structures "of rectangular form boarded over." Their average

\footnotetext{
37 Woods, Spunyarn, 1: 270-75; Report, October 1869, TNA, FO195/847, 537.

38 Woods, Spunyarn, 1: 270ff.

39 Osman, 61.

40 Woods, Spunyarn, 1: 273

41 Henry Elliot to Lord Clarendon, 14 September 1869, TNA, FO78/2083, 251.

42 TNA, FO195/847, undated, 517.
} 
height was forty-five feet. ${ }^{43}$

Referencing the Levant Herald - the foremost newspaper of the Englishspeaking community of Constantinople and beyond-the Liverpool Mercury reported that nine beacons had been erected by early April 1868 and that the remaining five would be in place by the end of the month - six on the European side and eight on the Asian, which was fewer than shown on Woods' plan. The rocket batteries had been ordered from London: there would be four on each side of the Bosphorus mouth. The report confirmed that the lightship was being constructed in the Constantinople arsenal according to a plan drawn by Trinity House. ${ }^{44}$ On 1 June 1868, the engineering journal Artizan reported that two refuge houses had been built on the Asian coast by this date, and six more were in the course of construction. ${ }^{45}$ By October, eight had been completed. ${ }^{46}$

Woods" "Notice to Mariners" was summarised, and the form and location of his beacons described in the Nautical Magazine and Naval Chronicle for 1868. This periodical of information essential to mariners advised, prematurely, that the lightship was to be in position by August 1868. The location of beacons, rocket stations and refuge houses was also recorded. ${ }^{47}$ The 1869 edition of the Nautical Magazine provided more precise information about these facilities, describing them in the context of Woods' detailed topographical notes which also located two "False Entrances"- another west of Karaburun on the European side in addition to that west of Şile. ${ }^{48}$

Woods relates that he was engaged in the work of the commission through 1868 and 1869. He oversaw the building of the lightship in the arsenal, being ever attentive to shoddy workmanship and use of poor materials. He designed the beacons and the refuge houses and supervised their construction. The rocket batteries and lifeboats obtained via Trinity House reached Constantinople safely. ${ }^{49}$

Woods and Ahmed Bey examined the Bosphorus entrance from a paddlesteamer, taking soundings and preparing a chart that the commission recognised as a work of the greatest importance for all sailing there. Woods also spent time with Ahmed Bey at the village of "Anatoli-Kavak." today Anadolu Kavağ1, on the Asian side of the Bosphorus. ${ }^{50}$

Trinity House sent experienced seamen from London to organise the lifeboat service and command the lightship. Samuel Palmer and John Doyle of the UK Coastguard Service were responsible for the lifeboats, and they would soon begin

43 TNA, FO195/847, undated, 516.

44 Liverpool Mercury, 21 April 1868.

45 Artizan 19 (1 June 1868), 127-28.

46 Bulletins and Other State Intelligence for the Year 18694 January 1869, 15-16.

47 Nautical Magazine and Naval Chronicle for 1868 37: 276-78. For information on this periodical, see Megan Barford, "Fugitive Hydrography: The Nautical Magazine and the Hydrographic Office of the Admiralty, c.1832-1850," International Journal of Maritime History 27 (2015), 208-26.

48 Nautical Magazine 1869 38: 490-96.

49 Woods, Spunyarn, 1: 294.

50 Ibid., 1: 287-88,294; Commission Internationale, 22 April 1869, TNA, FO195/847, 539. 
training local men for this work. The lightship equipment and instruments were on their way in mid-1869, and the lightship itself, with its "fog bell" that worked by clockwork, was to be anchored in early September. The lateness of the season imposed some urgency, but things seemed to be going fairly smoothly. ${ }^{51}$

Nine days before the lightship was to be deployed, however, Woods learned that the vessel that was to tow it into place had been ordered to Smyrna (today, İzmir) to take on cases containing the architectural remains of the newly discovered Temple of Diana at Ephesus. Heading to Anadolu Kavağ1, he found the lightship's local crew about to "bolt," despite their high pay, because a northeasterly gale had set in and they were afraid. Woods admits that he himself was apprehensive. Although desertion was averted, there were other teething troubles: two steam vessels were necessary to tow the lightship from Kavak to its moorings outside the Bosphorus mouth, but there was only one available and its towing hawser was in bad condition. Woods received no response to his request for replacements. His overriding concern was that because the mooring of the lightship had been announced, shipping searching for it would run aground if it was not in place at the appointed time. ${ }^{52}$

After blowing for several days, the storm abated and in the early hours of Saturday, 11 September, towed by a single paddle steamer, the lightship left harbour in a big sea. Visibility was very poor, and Woods navigated with the help of a lead line, his earlier soundings having afforded him intimate knowledge of the bottom. After thirteen hours at sea, during which time they covered fifteen miles, they reached a depth of seventy-five fathoms and the two experienced captains sent by Trinity House anchored the vessel in the pre-determined location. ${ }^{53}$

The two captains upon whom Woods relied were James Mathewson and Richard Stavers, both previously employed in Trinity House's Light Vessel Service in British waters. The Turkish crew, he wrote, were "hors de combat," which should not have surprised Woods since he had earlier observed that no Turkish vessels ventured out into the Black Sea during the winter months. After bidding farewell to Mathewson and Stavers, Woods set off back to land on the paddle steamer. ${ }^{54}$

Woods' duties were officially at an end with the mooring of the lightship. Ambassador Elliot praised him for his zeal in completing the task, and reported to his superiors in London that it was Woods himself who had moored the vessel. ${ }^{55}$ But there was to be no rest, for on his return to Constantinople, Woods heard that the lightship had been hit by a steamer and vanished from sight. He set out to sea again, to find the ship still in place. He learnt, though, that the local crew were

\footnotetext{
51 Woods, Spunyarn, 1: 293-95; Memorandum, 11 May 1881, TNA, FO881/4428, 3.

52 Woods, Spunyarn, 1: 295ff.

53 Ibid., 1: 297-98; for a contemporary image of the lightship from a document in the Ottoman archives in Istanbul, see: https://m.facebook.com/RivaTemsilcisi/photos/a.10153709557138725/10 $154053043948725 /$ ?type $=3$.

54 Woods, Spunyarn, 1: 268,298-99.

55 Henry Elliott to Lord Clarendon, 14 September 1869, TNA, FO78/2083, 251-52.
} 


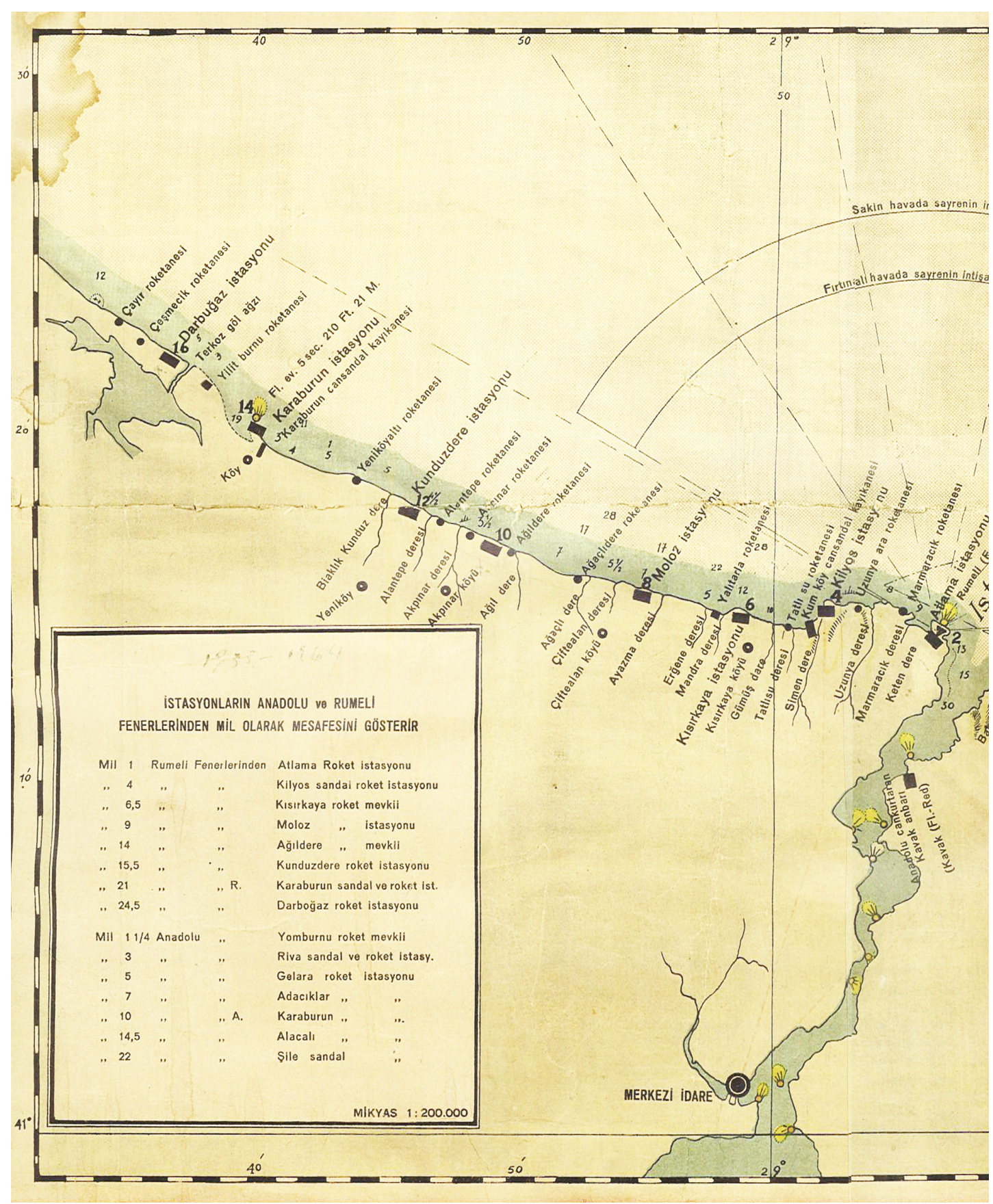

Transport Ministry - General Directorate of State Ports Management - Map Showing Black Sea Rescue Stations 


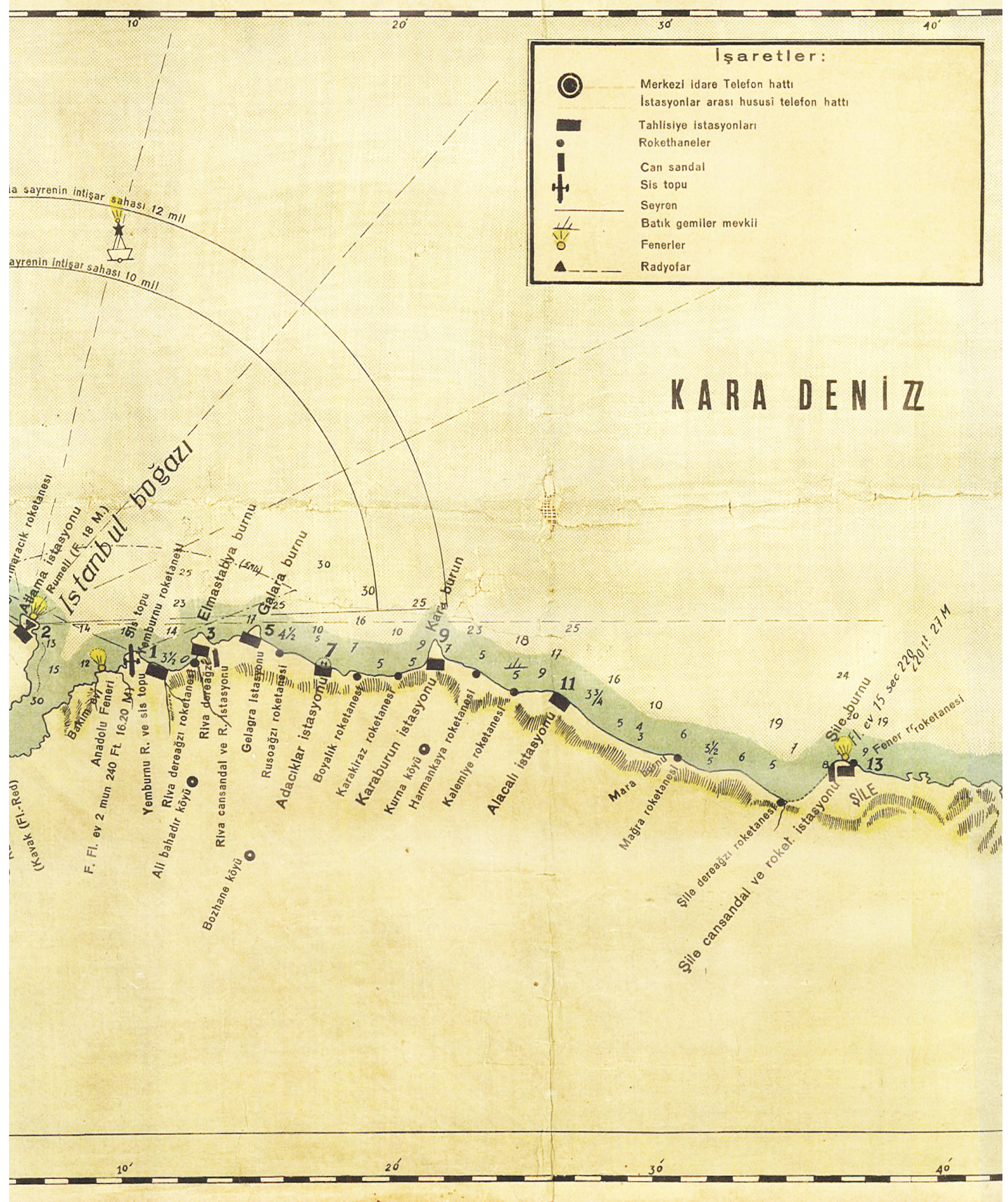

(Münkalat Vekaleti Devlet Limanları İşletme Umum Müdürlüğü Karadeniz Cankurtaran İstasyonlarını Gösterir Haritadır) 
becoming accustomed to their tasks, in what was proving to be an exceptionally stormy winter. ${ }^{56}$

A fortnight later Woods heard from the embassy that the vessel and all its crew were lost. He was told that the men had in effect mutinied, slipping the cables holding the ship in place, and sailing back towards the Bosphorus. As was the fate of so many other mariners, they had failed to find the mouth of the strait, and had drifted onto rocks at Şile and the lightship had broken up with all hands lost. The news came from a Greek captain who had seen the wreckage and the bodies of the English mariners. But Woods did not believe what he was told, not least because if there were no survivors, how did the story get out? When the Greek captain said that he had seen the bodies of six or eight Englishmen, Woods, knowing there to be only two, relaxed..$^{57}$

Some twenty years later, the lightship did go adrift. Woods writes that a day after he had recounted its story at his dinner table, news came that it had broken free. However, because it was summer and the sea benign, the ship was soon returned to its proper location. ${ }^{58}$

Woods' work on behalf of the commission was completed, but his life in Constantinople continued. In July 1869, Ali Paşa, now grand vezir, requested his transfer to the Ottoman navy; the appointment came into effect towards the end of the year. Woods eventually rose to the rank of admiral — Woods Paşa — and became an aide-de camp to Sultan Abdülhamid II. With the exception of World War I, Woods continued to make his home in the empire until his death in 1929. ${ }^{59}$

An early test of the new maritime safety system came only a month after the lightship was moored, on 8 October 1869. The machinery of the British steamer Caprera broke down and the ship ran aground off Riva while it was attempting to enter the Bosphorus after sailing from Odessa with a cargo of wheat. All but seven of the crew of twenty-four perished when they took to the lifeboats, and the survivors were helped ashore by sailors of another vessel. They spent the night in the refuge houses, where they were clothed and fed by the local authorities. ${ }^{60}$

By the end of 1869 , the embassy could inform London that the work contemplated for the safety of shipping had been "virtually accomplished." This included the erection of the coloured beacons and complete soundings taken to twenty miles offshore, and Woods' chart of the coast showing these features was available for sale; ${ }^{61}$ the lightship with all its equipment was in position; four

56 Woods, Spunyarn, 1: 299.

57 Ibid., 1: 300 .

58 Ibid., 1: 301.

59 Yusuf Osman, "On the trail of the elusive admiral. Admiral Sir Henry Felix Woods Pasha (KCVO, Grand Cordon of Mecidiye and Osmaniye and Knight of the Saxe-Coburg Order), http:// www.levantineheritage.com/testi39.htm.

60 Henry Elliot to Lord Clarendon, 7 November 1869, TNA, FO78/2083, 357ff.

61 Copies of Woods's charts are held in the UK Hydrographic Office (A1439 and A1770, dated March 1869), but are too large to reproduce here. I thank former Hydrographer of the Navy, Captain Mike Barritt, RN, for these references. 
lifeboats had been purchased from England; boathouses, refuge houses and rocket batteries had been built, and lightship captains and lifeboat instructors had been employed from England. The building of the coastal road was still outstanding and the parties concerned continued to argue about the levy on shipping that would fund maintenance of the lightship in particular. ${ }^{62}$

On the penultimate day of 1869 , delegates from eight of the countries that sat on the commission sailed out into the Black Sea to visit the lightship and inspect the rescue facilities on the Asian coast. They found the vessel to be solidly constructed and able to withstand bad weather, but recorded a number of problems that it seemed Woods' careful attention to detail had been unable to avert. The two English captains had their own list of items they lacked or that required repair. Among the latter, they complained that although the ship's lighting apparatus was of good quality, the light did not burn as brightly as it should and, despite repeated demands, proper cleaning materials still had not been supplied. ${ }^{63}$

The delegates were impressed by the dedication of both captains and crew, noting that the conditions in which they found themselves required attributes that set them apart from ordinary seamen. They praised those in charge for keeping the men healthy and their morale high. They considered the crew overnumerous, and proposed that caulkers and carpenters, and others with the necessary skills to carry out the outstanding repairs, replace some of them. The crew had not been paid by the Ottoman authorities for three months, almost since they started serving on the lightship. Nor did they have winter clothing or soap, and fresh water was not of adequate quality. Those responsible for tending to the lanterns were underpaid for performing this difficult task, as were the highly experienced English captains.

The delegation next inspected some of the beacons on the Asian coast, the rocks that were painted blue as a navigational aid, and the refuge house and lifeboat at Riva. They found the beacons to be in good condition and declared the painted rocks to be an extremely important aid to shipping. ${ }^{64}$ However, their limewash paint needed renewing and they would have to be repainted every year, and a larger area of rock needed to be painted so they were visible from further offshore. The Riva refuge house had a good supply of firewood, a stove and supplies for the rescued. The delegates recommended that each refuge house have a small rowing boat because the men working in these outposts needed occupying in order to keep their spirits up. In addition, they needed lanterns for the night time.

The delegation found the lifeboats and rockets to be disorganised. Some sixty men had been engaged locally for the lifeboat and coastguard service, and the lifeboat captains sent by Trinity House-Palmer and Doyle-were ready and

\footnotetext{
62 Henry Elliot to Lord Clarendon, 20 December 1869, TNA, FO78/2083 399ff ; cf. Memorandum, 11 May 1881, TNA, FO881/4428, 4-5.

63 Report of the delegates of France, Northern Confederation, Russia, Italy, Portugal, Sweden, Spain $\&$ Netherlands on the state of the lightship and other improvements at the mouth of the Black Sea in December 1869 - January 1870, TNA, FO195/847 549ff.

64 cf. Nautical Magazine 1869 38: 490ff.
} 
waiting. However, three of the lifeboats had never left their houses, and the fourth, destined for Şile, was still in the arsenal because its privately funded house had not yet been paid for and remained unbuilt. The coastguard had not yet been trained how to use the rockets, and it appeared that the coastal garrisons had not been given orders to assist with them.

The delegates' report concluded that the rescue service could only work if it was strictly ordered. The lightship needed frequent inspection, as did both coasts, and deficiencies, whether repairs or items lacking, demanded prompt action. They proposed that the Ottoman Lighthouse Administration (Memalik-i Mahrusa Fenerler Idaresi) should run the service.

The lifeboat service soon came into its own, when two Greek ships carrying grain from the Danube were stranded off the Asian coast in a snowstorm on the night of 29 January 1870 . The rockets at Eureké (sic) Point ${ }^{65}$ were fired, and eleven out of twelve crew rescued. The crew of seven men from a third Greek vessel were also saved, and the next day the lives of another seven on board yet a fourth Greek vessel stranded off the European coast were saved by the lifeboats. ${ }^{66}$

These rescue operations were among the first that the new maritime safety service enabled. It continued to develop: by June 1870, eight stores to supply the rescue service were being established, and six months later, the British consul general, Sir Philip Francis, recommended the fitting out of a second lightship and the laying down of buoys - the lines of buoys recommended by Schultze in 1863 had not been part of the scheme as realised by Woods and his fellows. ${ }^{67}$

Palmer and Doyle continued their work, Palmer on the European side and Doyle on the Asian. In the first three years that the rocket and lifeboat services functioned, some 120 lives were saved, and valuable cargoes besides. ${ }^{68}$ In April 1878 , Palmer was drowned in the course of his duties, trying to save an overcrowded refugee ship that had mistaken the Bosphorus entrance- the refugees aboard were probably some of the thousands who fled the Ottoman-Russian war of 1877-78. The lifeboat was nowhere nearby at the time. Palmer fired the rockets carrying to the vessel the lines that would be fixed to it. Thirty-two people made it to shore in the baskets running along the lines but ninety-six drowned. ${ }^{69}$

The following year a memoir describing the daily life of Palmer's son, also Samuel, appeared in the Morning Post. Written by Sir George Thomas, described as an Constantinople resident "connected with the Imperial Ottoman Bank," it described Palmer's dwelling, close by a beacon, "on a grassy headland some six miles from the mouth of the Bosphorus." Palmer Jr's wife was with him, and fifteen local men lived in an adjacent bothy. Thomas writes that the place where Palmer Jr

65 Eureké Point is presumably the "Clashing Rocks" of antiquity, off Rumeli Feneri; the site is still known as Öreke taş1.

662 February 1870, TNA, FO195/847, 558.

67 Memorandum, 11 May 1881, TNA, FO881/4428, 7-8.

68 Nautical Magazine 1872 41: 276.

69 https://history.state.gov/historicaldocuments/frus 1880/d607. 
lived had a fort, and the Belgrade forest was visible, which suggests a location in the vicinity of Kilyos. Moreover, Thomas mentions Kilyos (as Kilia) as one of the two most important stations on the European coast, and as having a lifeboat. After a rocky start, Palmer Sr seems to have trained the lifeboat crews well, and Thomas cannot praise them enough, for their skill, strength and endurance. Thomas also wrote of the rockets for which Palmer Jr was responsible - presumably because the Ottoman authorities had not instructed local garrisons to operate themnoting that the foreign mariners who plied these waters did not understand their use and that many lives - including that of Palmer $\mathrm{Sr}$ - had been lost through this incompetence. ${ }^{70}$

The British authorities apparently heard no more of the maritime safety system until Ambassador Henry Layard reported in 1880 that the salaries of those working in the lifeboat service were very low and so irregularly paid that the men threatened to resign. Layard mentioned that Palmer Jr had been adamant on this point, even calling meetings of his colleagues to agree a letter to the Porte insisting that the dues paid for the support of the lifeboat service not be diverted elsewhere. The enthusiasm of the Porte for the service had regularly been questioned by the foreign commercial interests sailing these waters. The apportioning of dues to pay for running it was an ongoing sore, and the sad reality was that it was underfunded. "Captain Woods Bey" was proposed as inspector of the service, but he did not take up this post. ${ }^{71}$

What then of the extant structures of the Black Sea maritime safety system introduced at the outset, that we see on our coastal hikes? Once we learned their history, we understood the brick towers to be watch towers, and the low buildings to be refuge houses and other facilities of the system whose establishment was spearheaded by Woods in the late 1860s. Knowing how they came to be there added new interest to our hikes.

Today, much of the coastline on either side of the Bosphorus is a sad place. Army bases occupy extensive tracts, which renders the landscape off limits but at least keeps it relatively unscathed. Other areas are also inaccessible, because they are leased to construction companies to dredge sand and dynamite rock for road building and other landscape destructive purposes of which the new Istanbul airport, covering an area of $76.5 \mathrm{~km} \mathrm{sq} .{ }^{72}$ is only the most egregious example. It extends to the coastal strip, and its associated infrastructure, from futuristic highways to enormous quarries, has irreversibly blighted this area of Thrace - flying over gives a startling perspective on what has been lost. The project for Kanal İstanbul-the proposed waterway connecting the Black Sea to the Marmara Sea west of the Bosphorus - threatens worse. At a minimum, it will destroy the shore of Terkos Lagoon, just as dredging has already destroyed sensitive ecosystems and historical

70 https://history.state.gov/historicaldocuments/frus1880/d607.

71 Memorandum, 11 May 1881, TNA, FO881/4426, 8ff.

72 https://en.wikipedia.org/wiki/Istanbul_Airport. 
sites, particularly on the European side. Military bases and turbocapitalism mean that some of the maritime safety system's structures cannot be visited; some have been demolished, and others remain to be identified.

Destruction of the facilities of the maritime safety system generally goes unremarked. Few know what these structures are, and fewer yet recognise their historic value. One case that caught media attention was the demolition of the disused Akpınar rescue station (Tahlisiye İstasyonu) on the European coast. (The term rescue station denoted a site that included several facilities of the maritime safety system.). In 2013, the coastguard service (Klyl Emniyeti) rented its 0.7 hectare site to a mining company for "development" as a marina, hotel and restaurant/cafe complex. Two years later, it was discovered that the renter was instead mining coal there. ${ }^{73}$ Investigations revealed that the rescue station had been demolished, and some fifty tons of coal extracted. According to the news report, this was not the first mining company that had hoped to rent the site, but the Council for the Protection of Monuments (Anitlar Kurulu) had hitherto banned construction and the coastguard had previously refused to rent it out. It is unclear what changed their mind. Local villagers alerted the authorities, but too late. ${ }^{74}$

The ongoing attention paid by the Ottoman and Turkish authorities to maritime safety in these waters is evident from the map of the rescue stations of the early Republican era (pp. 394-95). It shows the Turkish coastline on either side of the Bosphorus Strait, between Terkos Lagoon in the west and Kefken, beyond Şile, in the east. The map is undated, but written by hand on one of the legends is "19351964." We may hazard the assumption that it was current between these dates. The map was printed by the Transport Ministry, General Directorate of State Ports Management (Münakalat Vekaleti Devlet Limanları İsletme Umum Müdürlüğ̈̈), ${ }^{75}$ and records the facilities of the Black Sea maritime safety system - rocket stations (rokethanesi), lifeboat houses (cansandal kaylkhanesi), and rescue stations. It shows headlands (burun) and rivers (dere), as well as depths along the coast and at the Bosphorus mouth, and marks some inland villages. By the time this map became a reference tool, the maritime safety facilities for these waters numbered many more than were conceived of in Woods' scheme.

Comparing the facilities marked on the rescue stations map with those recorded as part of Woods' scheme shows their subsequent proliferation, even if the versions of Woods' lists that we have are incomplete. ${ }^{76}$ Perhaps the most obvious change is

\footnotetext{
73 Low grade coal has long been mined along this coast, and satellite photos on Google Earth show how greatly its beaches and their hinterland have been churned up in recent decades, before the current round of extraction of sand for construction.

74 https://www.istanbulhaber.com.tr/tarihi-akpinar-tahlisiye-istasyonunu-yikarak-komur-ocagiyaptilar-haber-235178.htm.

75 The Transportation Ministry (Münakalat Vekaleti) was established under this name in 1939 (cf. https://www.resmigazete. gov.tr/arsiv/4220.pdf), and the map may therefore make official the preexisting location of maritime safety facilities on these coasts.

76 For instance, although the commission delegates refer to the Riva refuge house in their report, it is not mentioned among the facilities of the maritime safety system located at Riva in the Nautical
} 
an increase in the number of coastal sites where facilities of the maritime safety system were positioned. There is a particularly notable increase in the number of rocket batteries, reflecting the fact that this coast remained a significant danger to mariners (see Tables $1 \& 2$ ). Woods' beacons have undoubtedly rusted away-we have not knowingly come across any remnants of them on our hikes. Indeed, no beacons are shown on the map; at some locations, such as Mağara and Alacal1, on the Asian coast, they appear to have been replaced by other facilities.

None of the sources we have seen, from the deliberations of the International Commission for the Improvement of the Navigation of the Black Sea Entrance to the Bosphorus etc that debated the components of the maritime safety system in the 1860s, to official documents, to newspapers and journals, make reference to watch towers among its features. Yet the watch towers that alerted those on land to assist those in peril at sea are perhaps the most distinctive of the structures we have happened upon. They have a high octagonal base with a slimmer, windowed, octagonal tower on top. If we are looking for clues that they were part of Woods' scheme, might we interpret Ambassador Lord Lyons' assertion in 1866 of the importance of coastal surveillance as a veiled reference to watch towers? ${ }^{77}$ Or the designation of the Elmas Tabya headland west of Riva as a "look-out station" for Riva in Woods' scheme? ${ }^{78}$ The inventory records the watch towers we have seen, as well as the other features of the system we have come across on our hikes.

The architectural style of the watch towers and the Riva rescue station, as of other facilities of the maritime safety system - such as the rocket batteries at Karakiraz and Boyalik on the Asian coast which, because we have not seen them mentioned in the 1860s, also appear to have been built later than the years Woods was active on this coast-is very similar. It seems that the style of the earliest structures was retained over a number of years, which makes the dating of individual structures elusive. ${ }^{79}$ As discussed in the inventory, dating the bricks of which they are built may offer insights into when they were constructed.

Magazine 1869 38: 494,495, whereas others, such as at Adacıklar, are.

77 Lord Lyons to Aali Pacha, 14 September 1866, TNA, FO195/847, 556.

78 Nautical Magazine 1869 38: 495.

79 The architectural style of the structures of the maritime safety system, with brick detail defining doors, windows, and walls, was widely used in the late Ottoman era; see, for example, photographs of the structures of the Terkos Pumping Station in Durusu village, which were built a few years later than those under discussion here: Devrim İsenkul, "Terkos Su Yoluna ait Yapılar" (MA thesis, Y1ldız Teknik University, İstanbul, 2019), 38-39. 


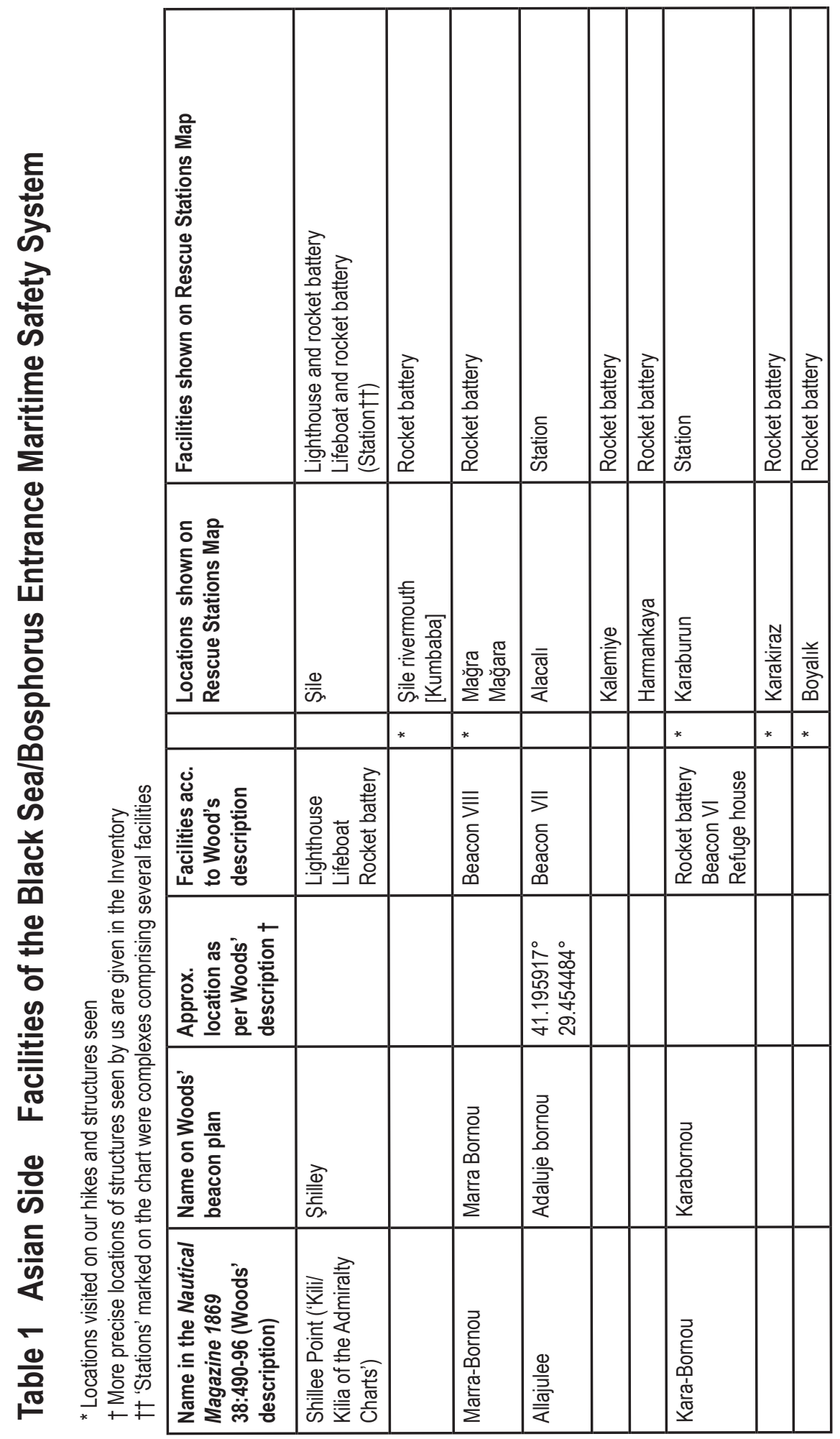




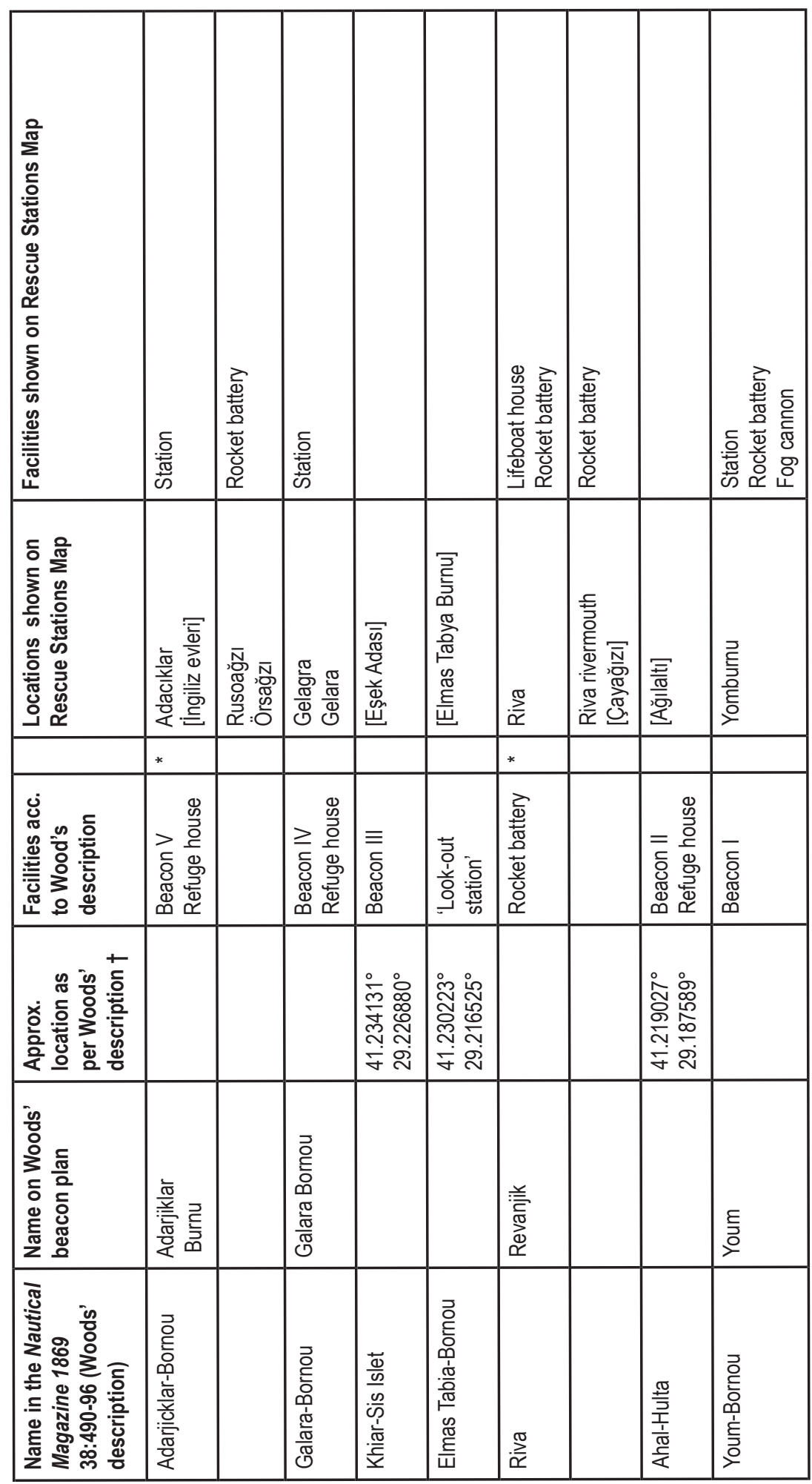




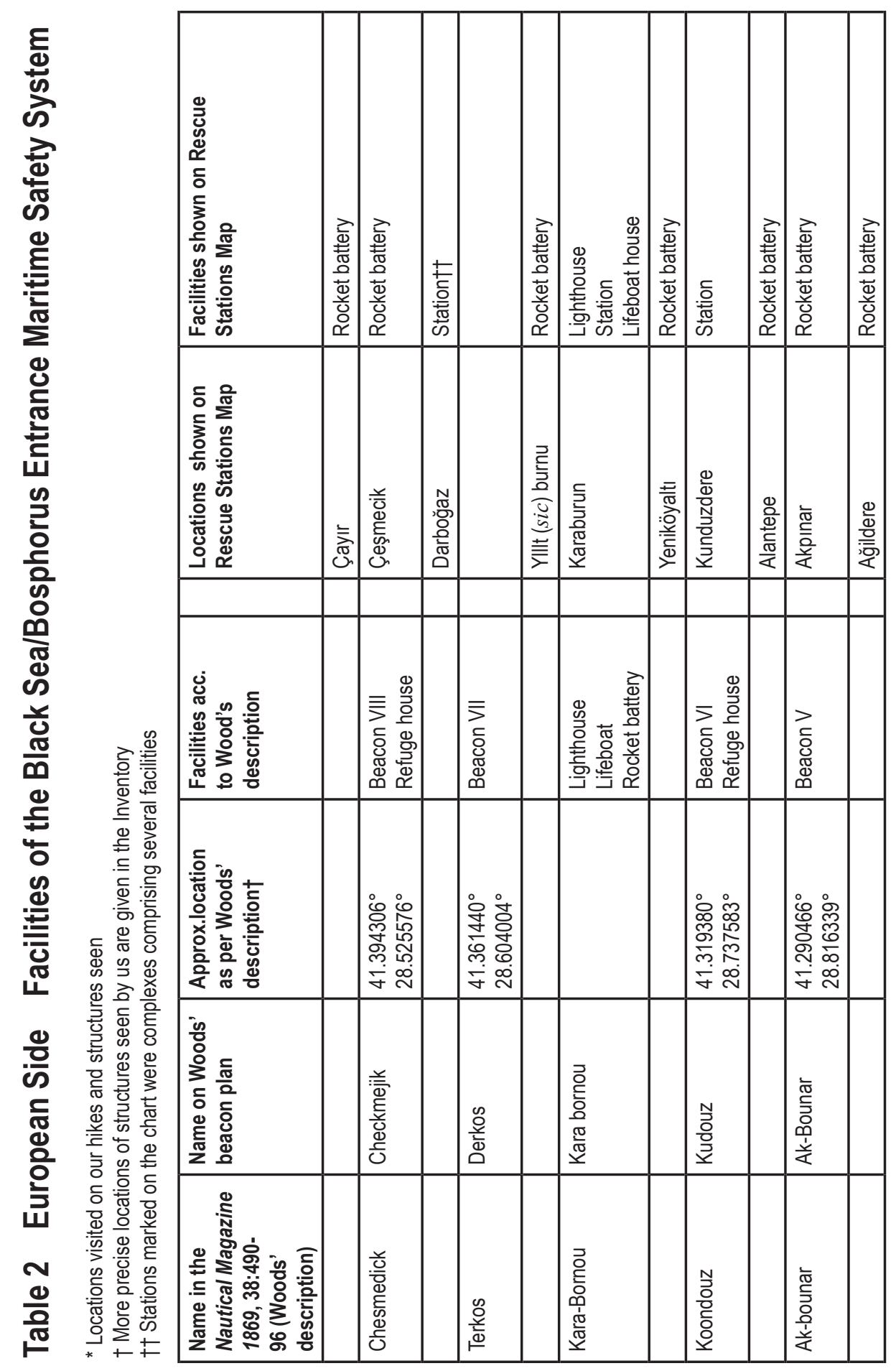




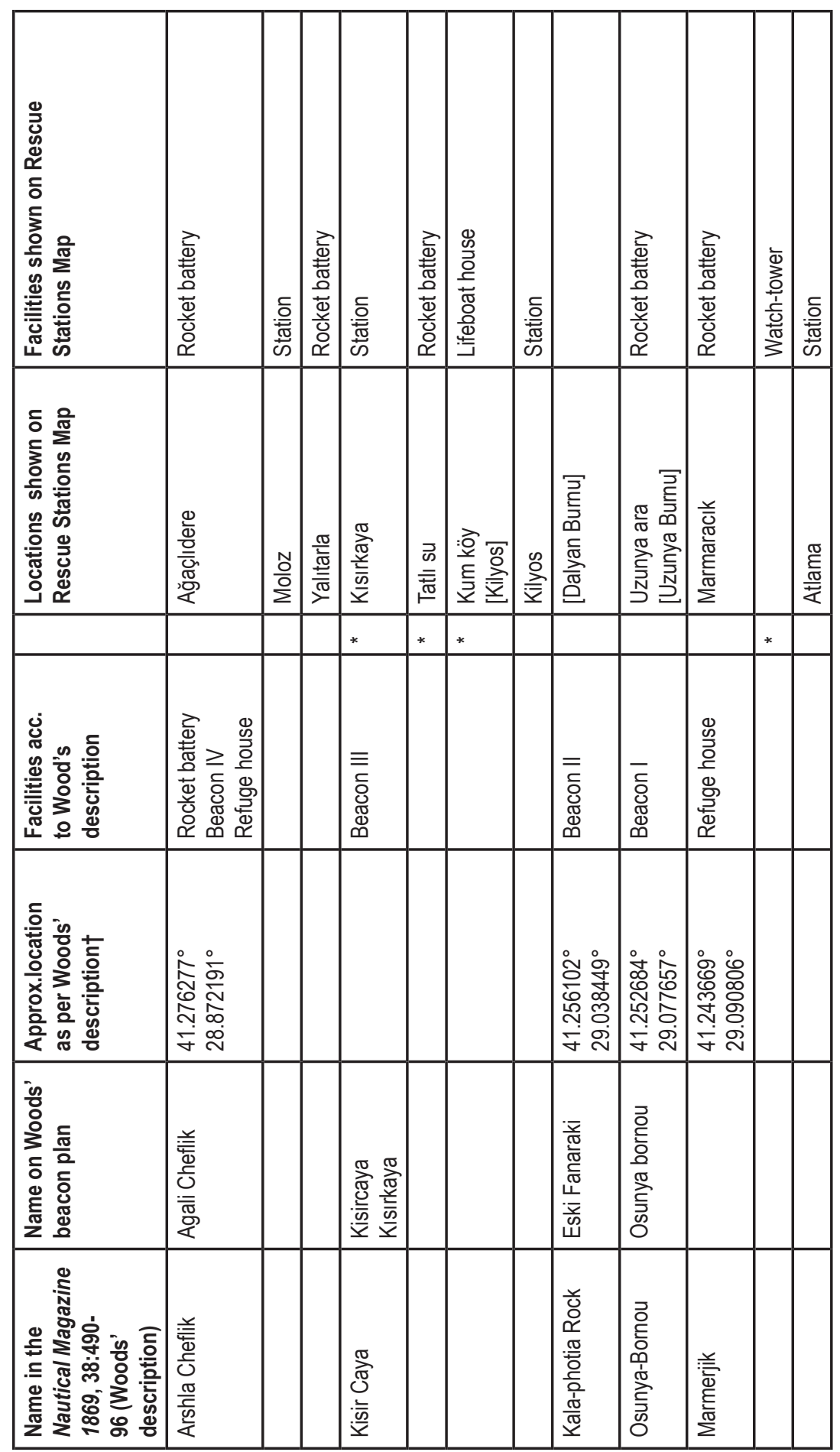




\section{Inventory of Sites of the Black Sea/Bosphorus Entrance Maritime Safety System}
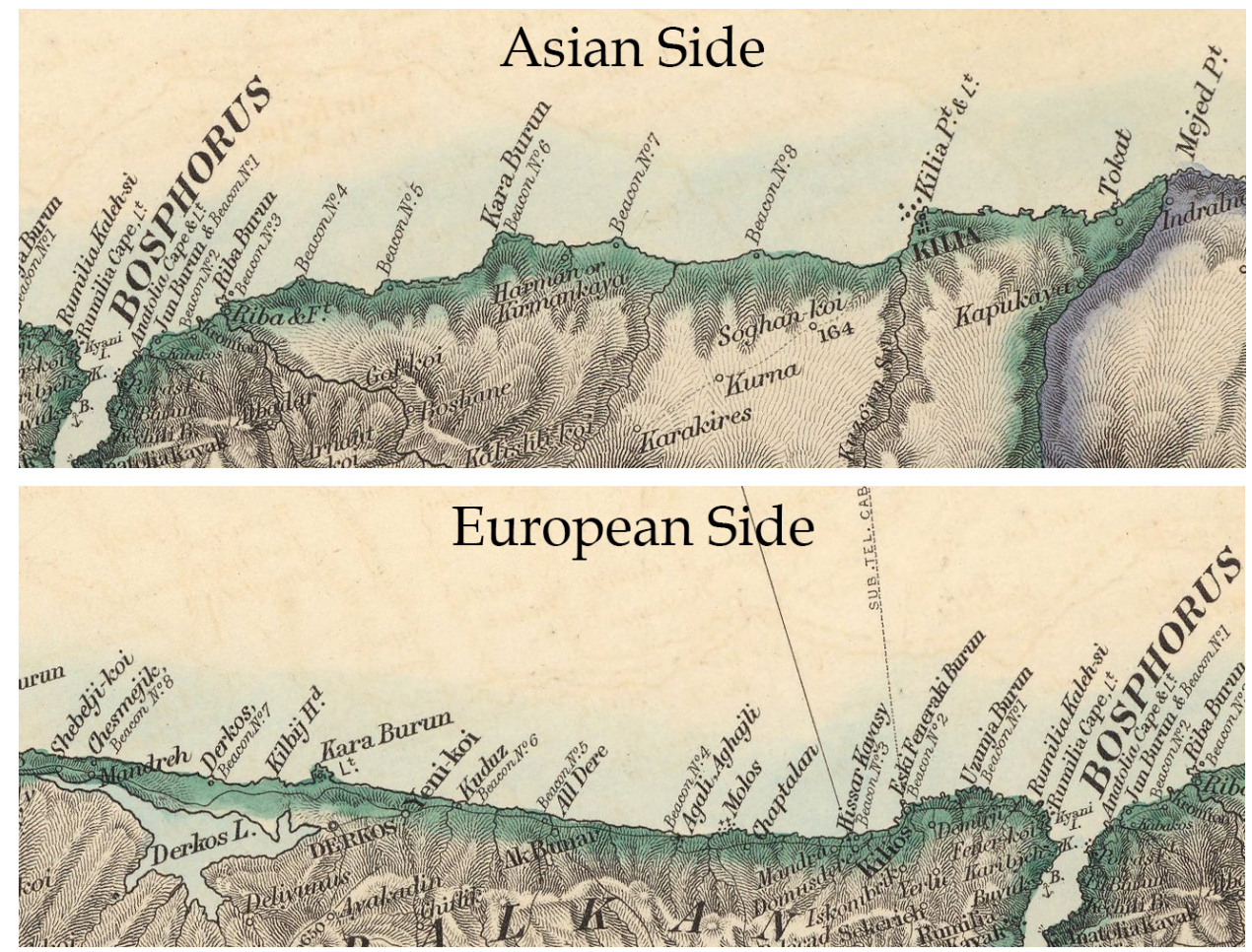

Details from "The Sea of Marmara" in Stanford's London Atlas Of Universal Geography, 1884 (David Rumsey Collection) 


\section{Şile}

Sile's lighthouse $\left(41.177837^{\circ}, 29.616404^{\circ}\right)$ is on a headland on the east side of the town; the Rescue Stations map shows a rocket battery nearby. The Şile station today comprises the refuge house, rocket battery and lifeboat station, which are $500 \mathrm{~m}$ west of the lighthouse. They are now far inland owing to infilling of the coast, on Plajyolu Sokağı. The refuge house is being restored for current use. A watch tower was also recorded here in $1999 .{ }^{1}$

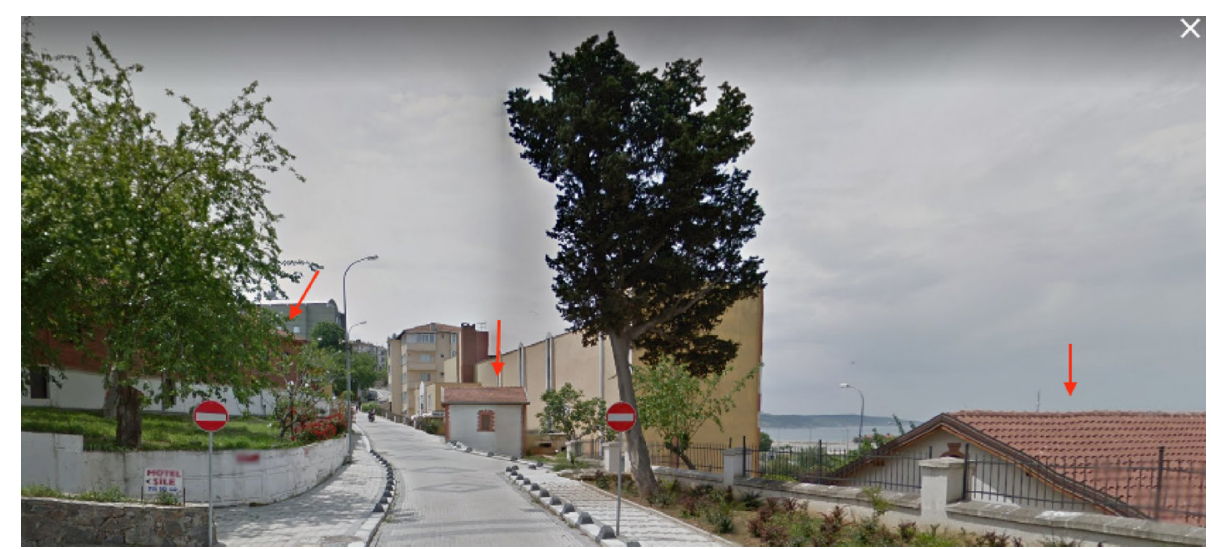

The refuge house is behind the tree on the left; the rocket battery is in the middle and the lifeboat station is below the modern road. (Google Street Map)

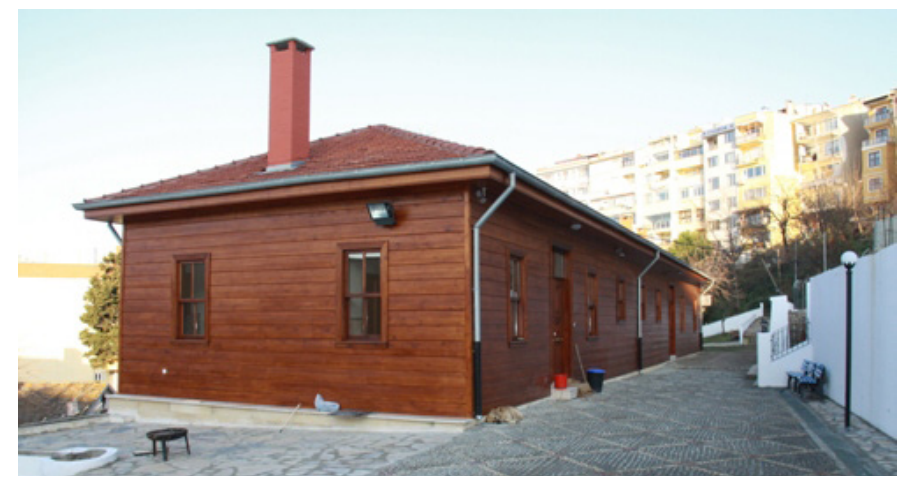

Refuge house (https://www.gidilmeli.com/Tahlisiye-binalari-sile/10841/1)

1 Reyhan Ay, "İstanbul Boğazındaki Deniz Fenerleri ve Tahlisiye Yapılarının Koruma ve Değerlendirilmesi” (MA thesis, Yıldız Teknik University, İstanbul, 2000), 125 


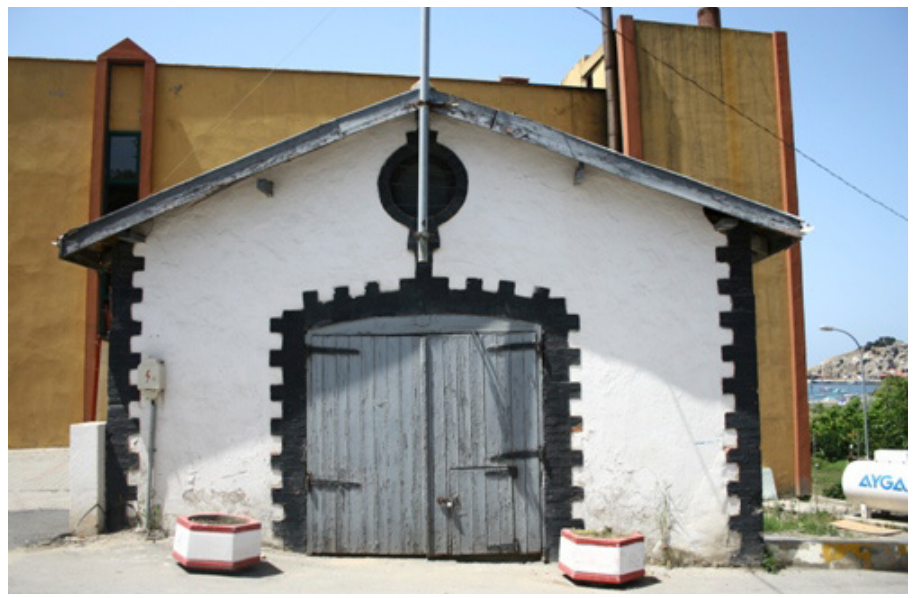

Rocket battery (https://www.gidilmeli.com/Tahlisiye-binalari-sile/10841/1)

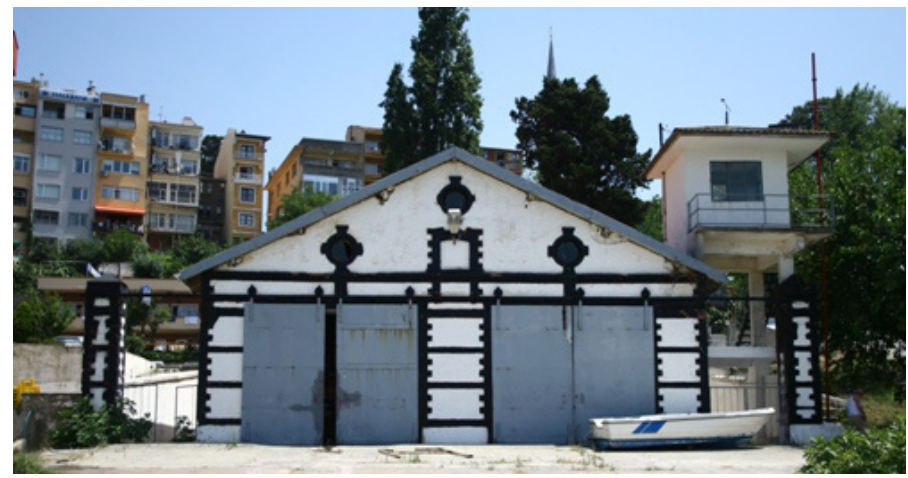

Lifeboat station (https://www.gidilmeli.com/Tahlisiye-binalari-sile/10841/)

\section{Şile rivermouth}

A rocket battery $\left(41.172778^{\circ}, 29.567357^{\circ}\right)$ is shown here on the Rescue Stations map. Situated high above the beach, it is today a restaurant that acknowledges the historic past of the building with information panels describing the part that rockets played in saving the crews of shipwrecked vessels. 


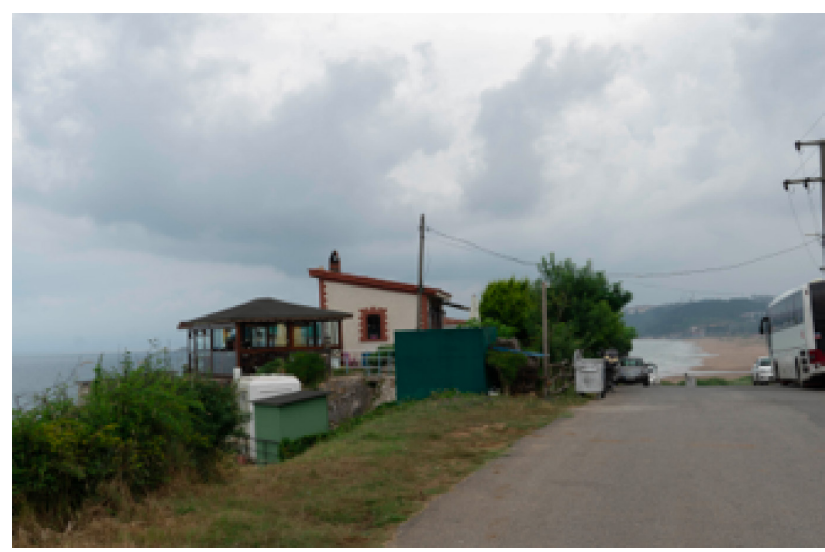

Rocket battery (photo: OG)

\section{Mă̆ra/Mă̆ara}

The rocket battery $\left(41.184284^{\circ}, 29.512765^{\circ}\right)$ marked on the Rescue Stations map is situated some metres above the beach. The name Mağara means "cave" in Turkish, and denotes the so-called Xenophon's Cave nearby.

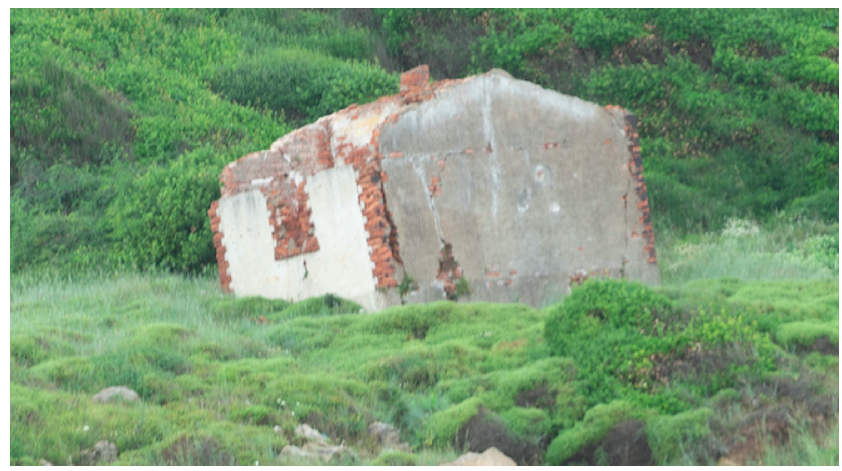

Rocket battery

West of Mağara is a long beach of shifting sands, with the villages of Doğancılı and Sahilköy spreading much of the way along, behind the coastal strip. In such an environment, the structures of the maritime safety system are likely to have been lost. We read that the refuge house and watch tower of the Alacalı station shown on the Rescue Stations map are extant ${ }^{2}$ but did not find them. West of Alacalı were the rocket batteries of Kalemiye and Harmankaya, both shown on the Rescue Stations map, which we also failed to locate.

\footnotetext{
2 http://www.sile.bel.tr/Page/Detail/5404.
} 


\section{Karaburun}

A station is marked on this prominent headland on the Rescue Stations map. In 1999, the complex included a refuge house, a watch tower-since repurposed as a light - and a rocket battery. ${ }^{3}$ The lifeboat house $\left(41.213894^{\circ}, 29.389427^{\circ}\right)$ is on the shore below. On 19 December 2018 a cargo ship sailing under the Comorian flag ran aground $\left(41.215724^{\circ}, 29.387382^{\circ}\right)$ in heavy seas at this "False Bosphorus." Its crew were rescued by the local coastguard; the ship's hulk remains where it came to rest.

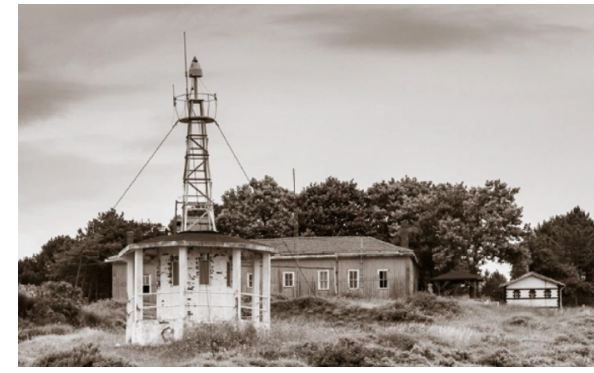

Watch tower base with refuge house behind

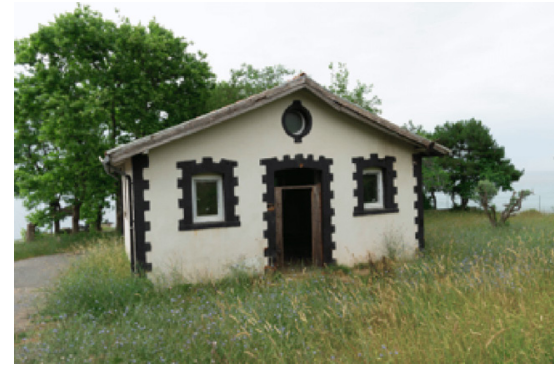

Rocket battery

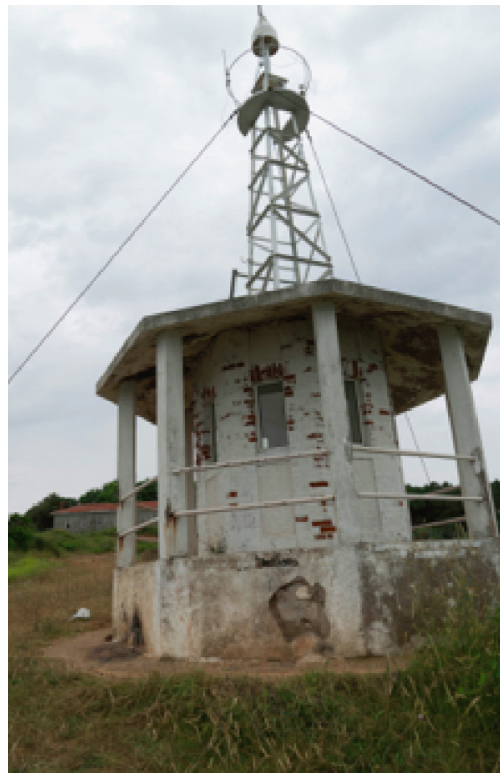

Watch tower base

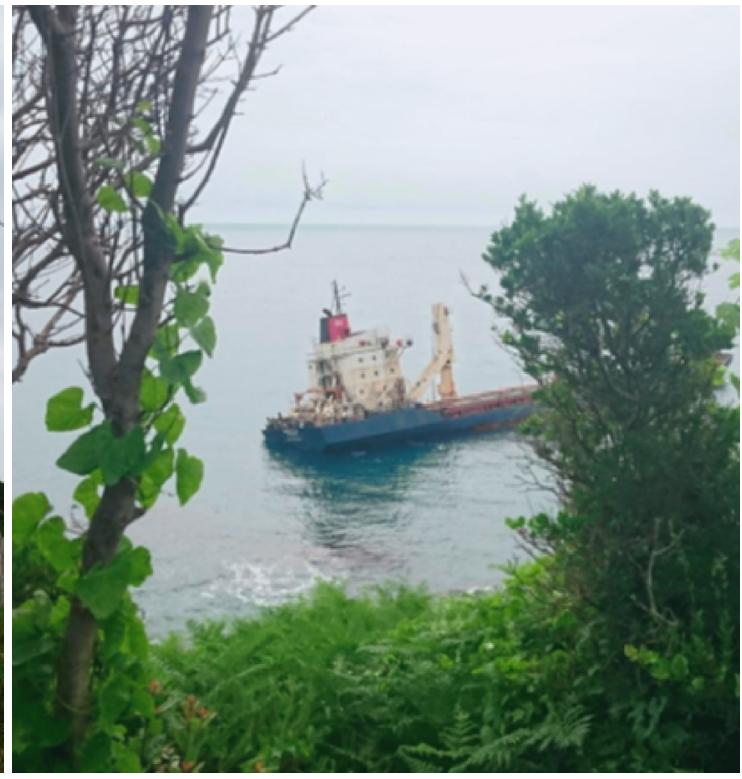

Shipwrecked Comorian vessel (photo: OG)

Ay, 123. 
Two rocket batteries are marked on the Rescue Stations map between Karaburun station and Adaciklar station. We saw two small huts along this stretch of coast, and assume them to be, respectively, Karakiraz $\left(41.210455^{\circ}, 29.358937\right)$ and Boyalik $\left(41.215801^{\circ}, 29.320863^{\circ}\right)$.

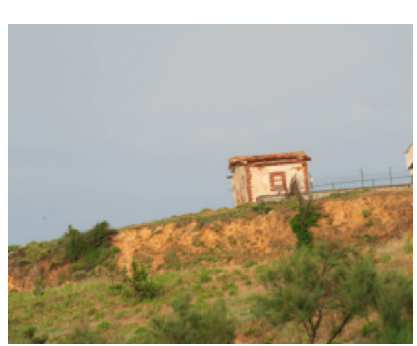

Karakiraz rocket battery

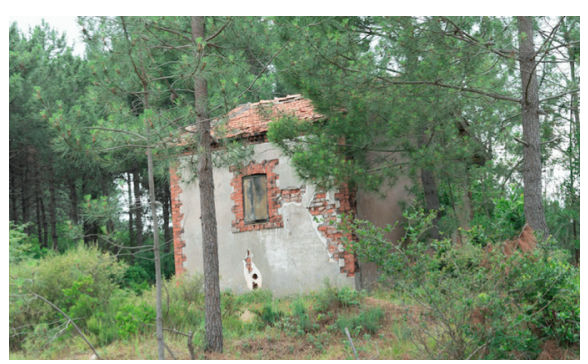

Boyalık rocket battery

\section{Adacıklar}

Adaciklar station is well preserved; it attracts local tourists and is used as a film set. It has not been possible for us to distinguish the different structures that make up the complex, apart from the watch tower $\left(41.221804^{\circ}, 29.297037^{\circ}\right)$, which has been reroofed since we first saw it some years ago.

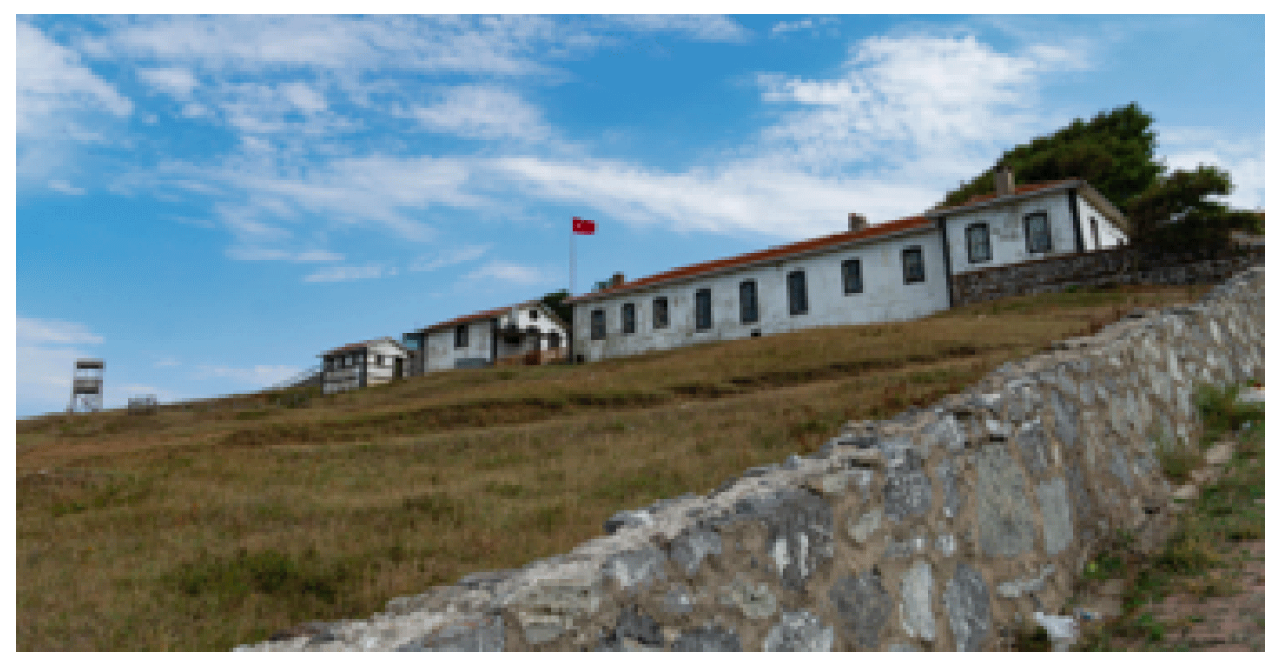

Adacıklar station

We have noted that watch towers are not mentioned as elements of the maritime safety system by Woods, nor marked on the Rescue Stations map. Some, at least, of the bricks used to build the Adaciklar watch tower are stamped on their visible face with the design of a star between two opposing crescents, with a pair of round discs outside each crescent, and acanthus leaves partly encircling these on each side of the brick, with a third acanthus leaf below. The other face of the bricks is hidden. This motif is that of Salomon Brick Factory in the Büyükdere suburb of Istanbul, on the European shore of the Upper Bosphorus. 


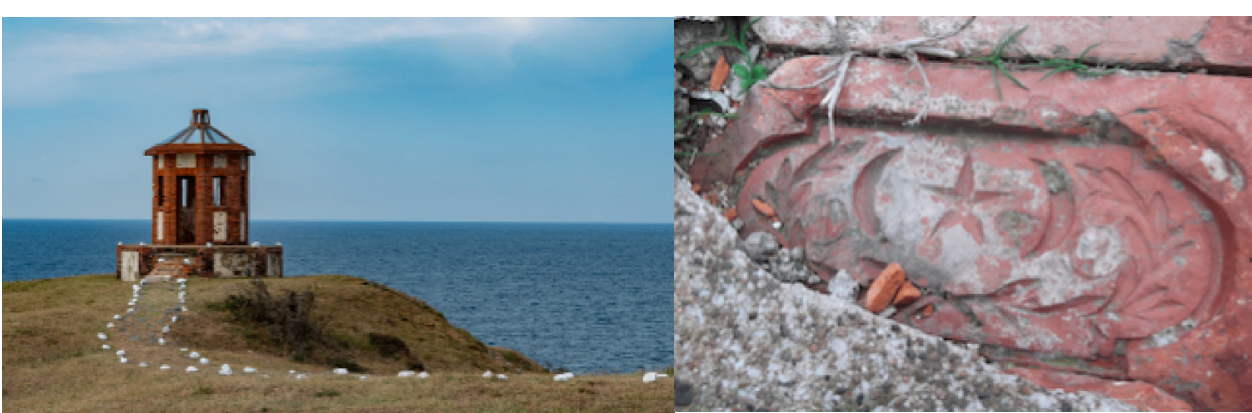

Restored watch tower

Watch tower brick with Salomon Brick Factory stamp.

The Salomon factory is thought to have begun production later than $1869,{ }^{4}$ when Woods carried out his work, but further research is needed to provide a more precise date. Once in possession of this information, and assuming the bricks are from the original structure, we will be able to suggest when the watch towers were built.

\section{Gelara}

A station is marked on this prominent headland on the Rescue Stations map; there is also a watch tower $\left(41.233186^{\circ}, 29.253838^{\circ}\right)$. Today the site is used as a cafe/picnic place.

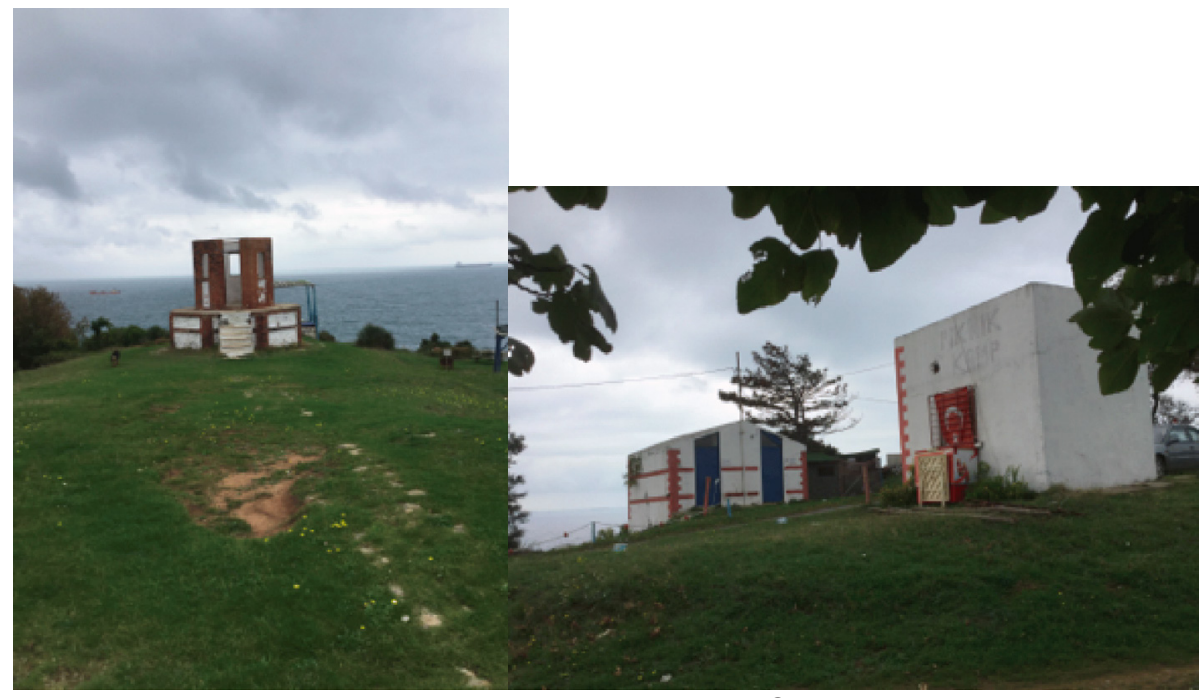

Watch tower

Gelara station

4 I am extremely grateful to Nevriye Öztürk who is currently (2021) writing her PhD thesis for Yildız Teknik University, Istanbul, on late Ottoman bricks and shared with me this information about the Salomon brick factory. 


\section{Riva}

Woods mentions a rocket battery at Riva and the Rescue Stations map also indicates a lifeboat house. The complex here $\left(41.227996^{\circ}, 29.223026^{\circ}\right)$ is perhaps the most extensive on this coast and, unlike others, has a wall all around. Yet like the watch tower, it is not mentioned in these sources. The several extant structures at Riva include a refuge house, a rocket battery, stables - stables were also found at other rescue stations - a watch tower, and a dilapidated timber clad mansion.

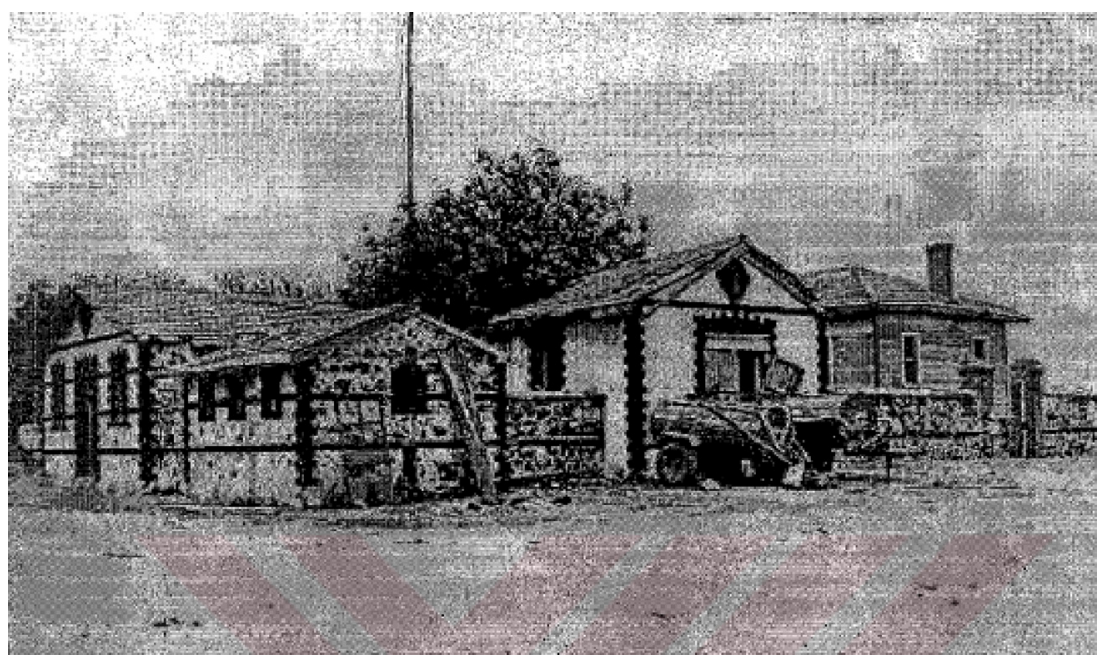

Riva station (Ay, 130)

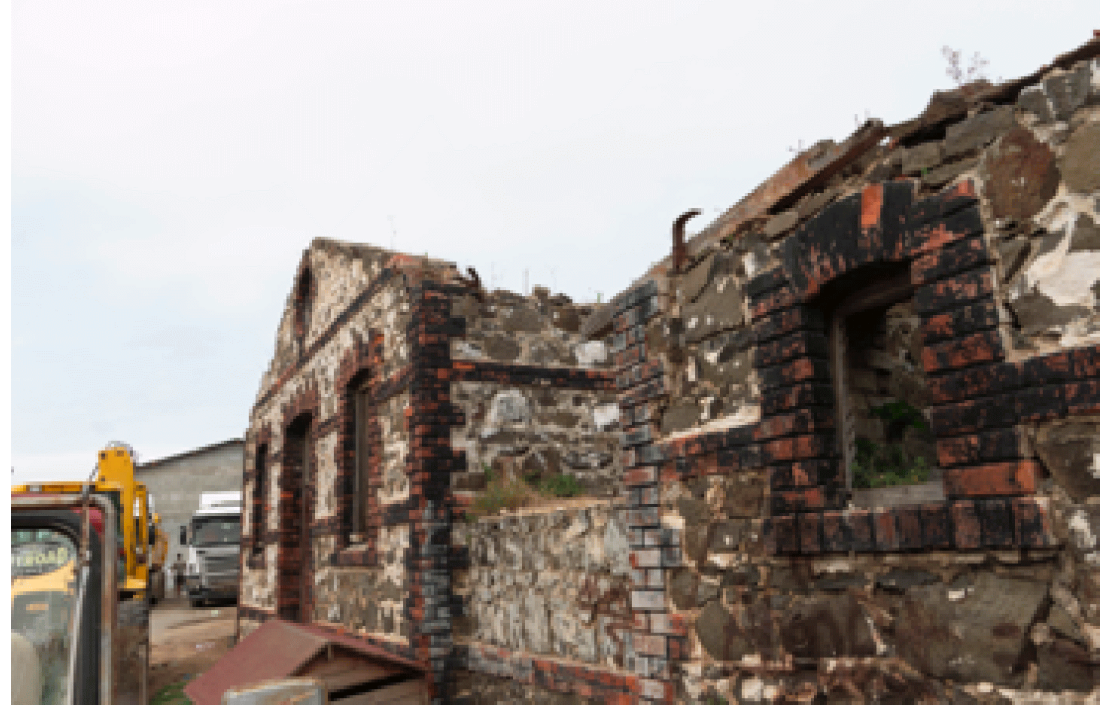

Riva station 


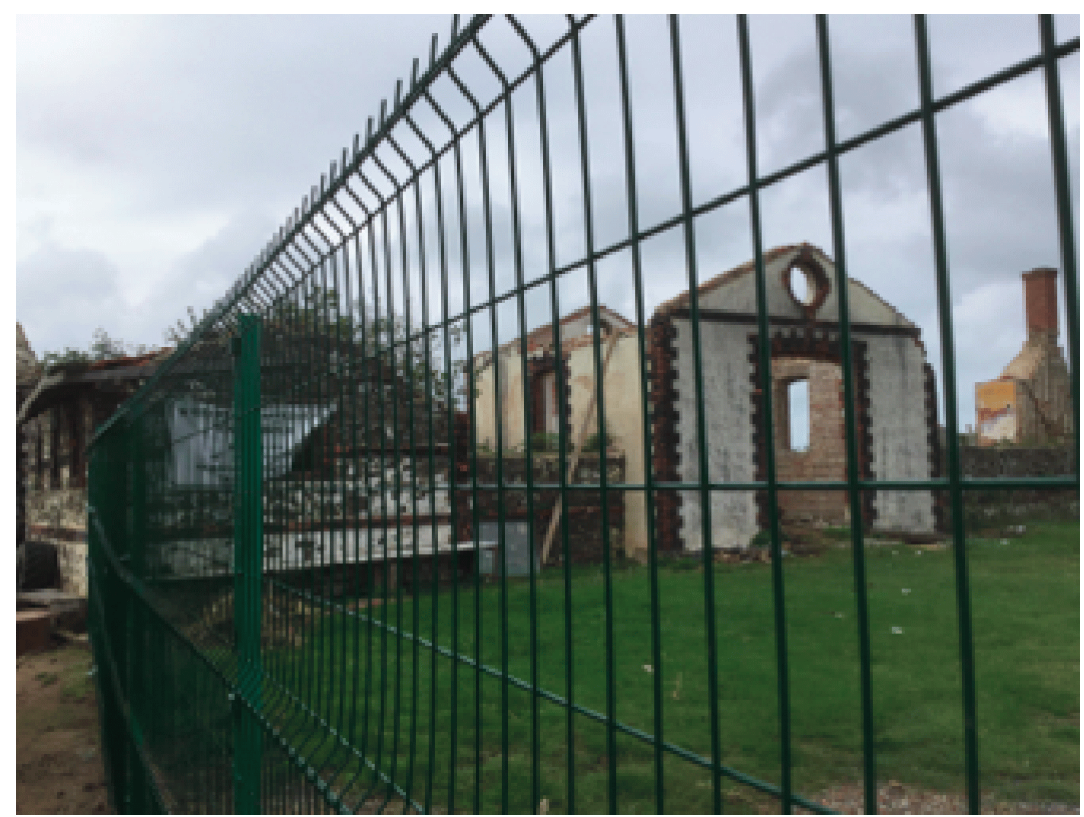

Riva station

The watch tower at Riva station is built into the wall of the enclosure and is a mightier structure than the free standing ones we have seen elsewhere. This complex has been left to decay, despite proposals for its rehabilitation and reuse. ${ }^{5}$

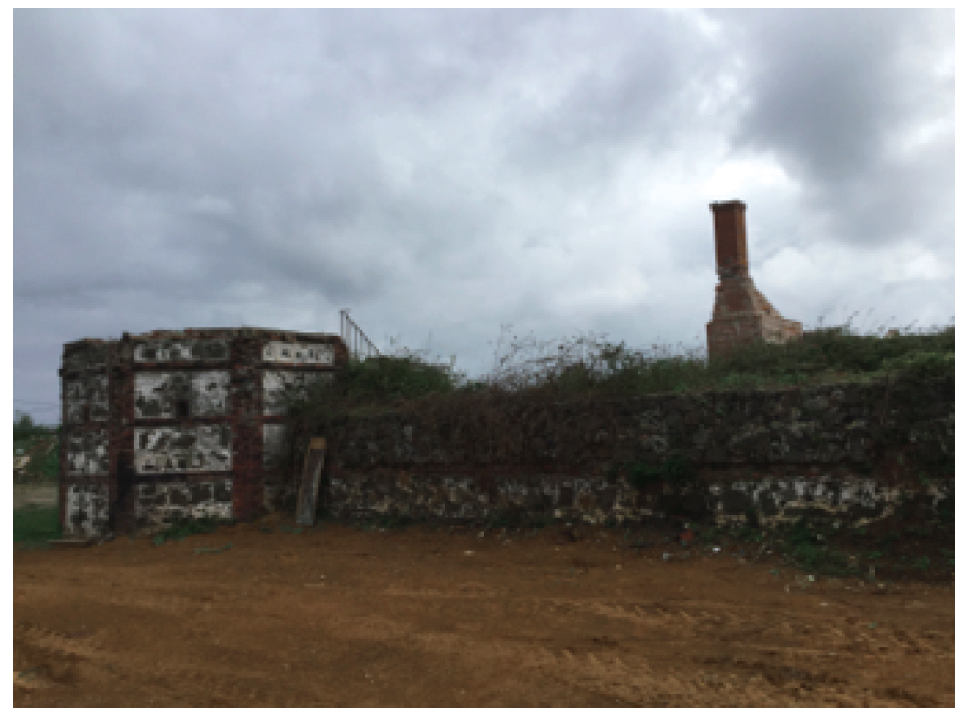

Watch tower base, with chimney of mansion within the walled enclosure

5 Ay, $130 \mathrm{ff}$. 


\section{Yomburnu}

The complex is marked on the Rescue Stations map as a station, and in 1999 included a mansion, a refuge house, a watch tower, stables and a rocket battery. ${ }^{6}$ It is within a military base atop the cliff. The lifeboat house $\left(41.218099^{\circ}, 29.162888^{\circ}\right)$ is on the shore below, in Kabakoz Bay.

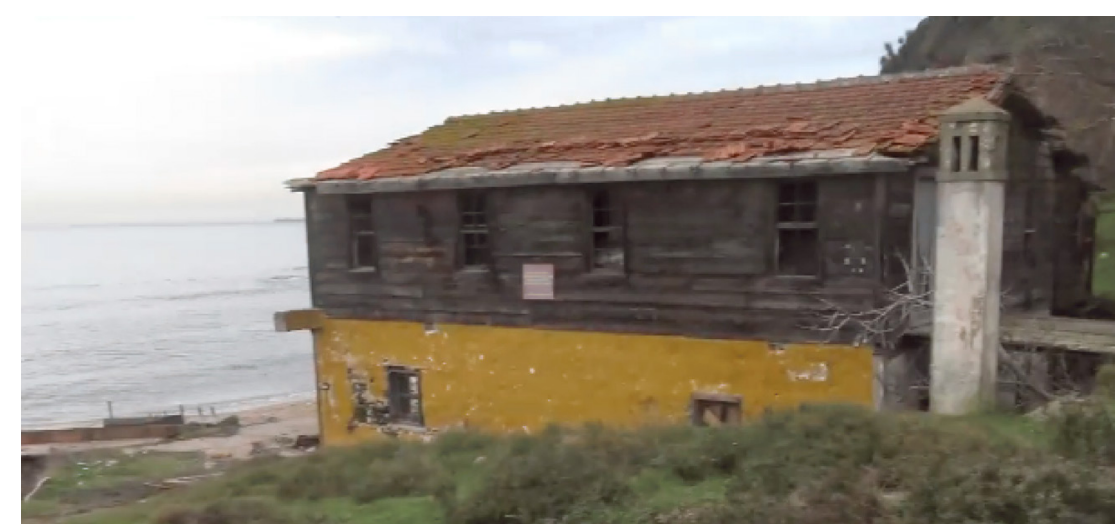

Yomburnu/Kabakoz Bay lifeboat house (https://vimeo.com/312029924)

\section{EUROPEAN SIDE}

Informed by Woods explorations, the Nautical Magazine 1869 describes this coast as "a long sandy beach from Kilios to the westward, merely divided by Karabornou." West of Karaburun, it consists for the most part of a long strip of land averaging $1.5 \mathrm{~km}$ across that is bordered in the south by Terkos Lagoon, and is described as "a sandy waste, the margin of which is strewed with the remains of wrecks." 7 This land is inaccessible on day hikes, and we have not yet walked here.

\section{Karaburun}

There has long been a lighthouse here $\left(41.347562^{\circ}, 28.682963^{\circ}\right)$. In 1999 , the complex included a refuge house, a watch tower, a rocket battery, stables, and a lifeboat house on the shore. ${ }^{8}$

Our hikes have taken us as far west as Yeniköy and Terkos villages. Between Karaburun and Yeniköy is a long sandy beach that at Yeniköy gives way to the most heavily re-formed landscape along these coasts, thanks to the new Istanbul airport and associated dredging and quarrying. We have been unable to locate extant structures of the maritime safety system here.

Ay, 123.

Nautical Magazine 1869 38: 490,496.

Ay, 127. 


\section{Kısırkaya}

The station $\left(41.252595^{\circ}, 28.977180^{\circ}\right)$ shown on the Rescue Stations map is east of the village. It is now a private home and is therefore hard to view.

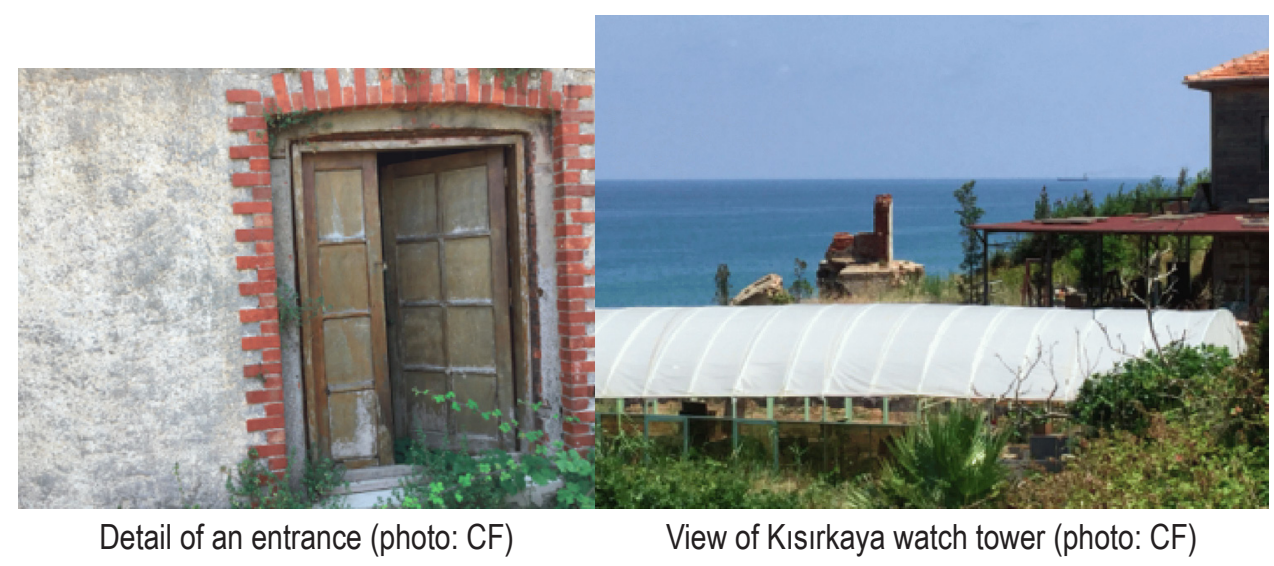

\section{Kumköy/Kilyos}

Kumköy is a now little used name of Kilyos. Its lifeboat house $\left(41.247671^{\circ}\right.$, $29.034754^{\circ}$ ) is in the small port.

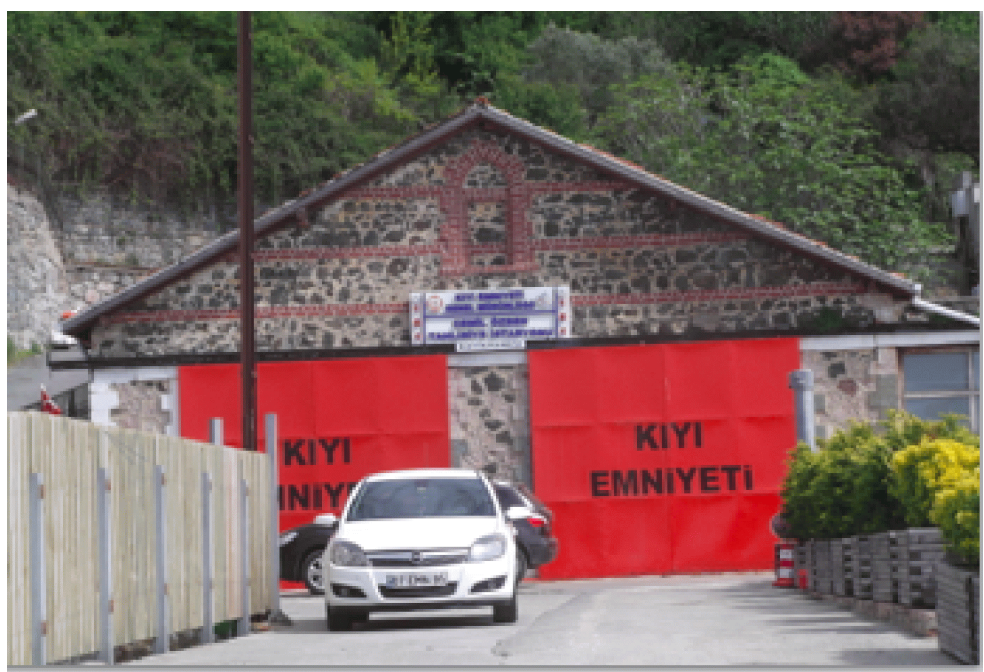

Kumköy/Kilyos lifeboat house (photo: CF)

Kilyos station is located east of the village centre, on Tahlisiye Caddesi (Rescue Boulevard), uphill from Woods' Eski Fanaraki beacon. In 1999, facilities 
included a refuge house, a rocket battery and a watch tower. ${ }^{9}$ The rocket battery has recently been restored.

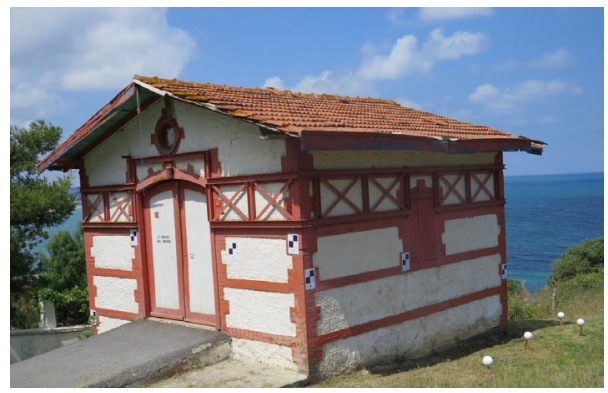

Restored rocket battery

(https://www.facebook.com/CAGrestorasyon/posts/2125038764229894)

This isolated watch tower, $\left(41.239478^{\circ}, 29.104262^{\circ}\right)$, whose name we do not know, stands some $800 \mathrm{~m}$ northeast of Rumeli Feneri village.

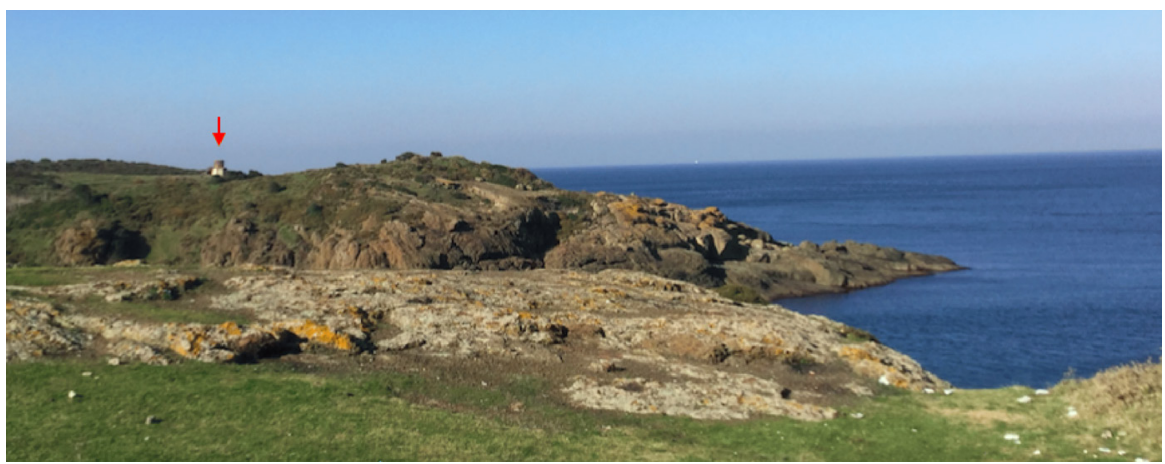

View of watch tower from the east

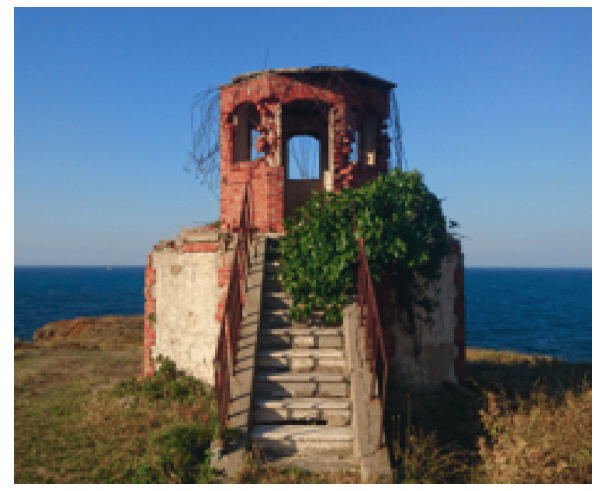

Watch tower (photo: OG)

$9 \quad$ Ay, 126. 


\section{POSTSCRIPT}

During editing of this article we came upon another structure $\left(41.245258^{\circ}\right.$, $29.012456^{\circ}$ ) between Kilyos and Kisırkaya on the European side. According to the Rescue Stations map, it seems to be the Tatlı su rokethanesi (Tatlı Su [Engl. sweet water] rocket battery); the name 'Tatlı su' implies there is a spring or stream nearby, which is confirmed on Google Earth.

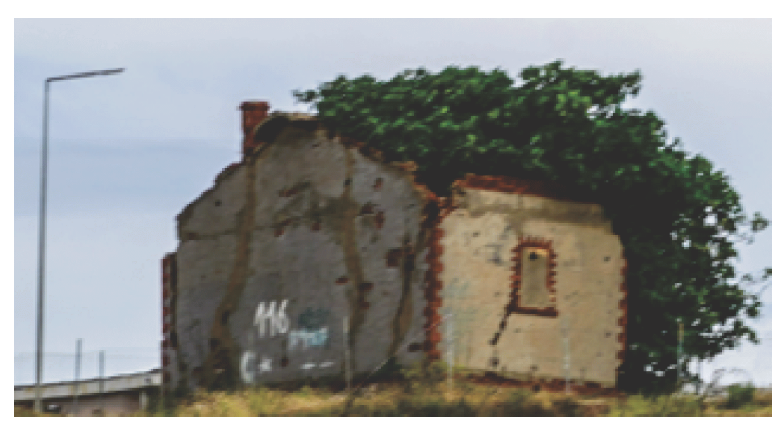

